Saint Louis University School of Law

Scholarship Commons

All Faculty Scholarship

2013

United States of America: The Burden of Proof in Tax Matters

Henry Ordower

Follow this and additional works at: https://scholarship.law.slu.edu/faculty

Part of the Tax Law Commons 
S A I N T L O U IS

$\begin{array}{llllllllll}U & N & \text { I } & V & E & R & S & \text { I } & T & Y\end{array}$

\section{SCHOOL OF LAW}

\section{SAINT LOUIS UNIVERSITY SCHOOL OF LAW Legal Studies Research Paper Series}

No. $2011-12$

United States of America

The Burden of Proof in Tax Matters

prepared for the

European Association of Tax Law Professors 2011 Annual Meeting

Working Paper

Henry Ordower

Saint Louis University School of Law 
United States of America

The Burden of Proof in Tax Matters

prepared for the

European Association of Tax Law Professors 2011 Annual Meeting

by

Henry Ordower, Professor of Law

Saint Louis University School of Law

This report will use the following abbreviations: ${ }^{1}$

Appeals refers to the Office of Appeals within the IRS.

Chief Counsel refers to the principal legal advisor to the IRS.

Code refers to the Internal Revenue Code of 1986, as amended, which is Title 26 of the United States Code. The United States Congress, with the agreement of the President, enacts the statutes that are in the Code. The Code constitutes the tax laws of the United States.

Commissioner refers to the Commissioner of Internal Revenue who is the chief executive officer of the IRS.

IRC (followed by $\S$ and a number) refers to the specific section of the Code.

IRM refers to the Internal Revenue Manual that contains a series of administrative guidelines and procedures for use by tax administrators.

IRS refers to the Internal Revenue Service, the branch of the United States Department of the Treasury that administers the tax laws of the United States and serves as the United States competent authority.

Secretary in the Code refers to the Secretary of the United States Department of the Treasury. This report generally substitutes IRS or government for Secretary in discussing statutes that refer to the Secretary.

Treas. reg. (followed by $\S$ and a number) refers to a regulation that the United States Department of the Treasury promulgates to interpret a section of the IRC. ${ }^{2}$

Part I. Burden of Proof, Generally.

A. Civil Matters: Administrative Settlement. In the United States, litigation to resolve a civil tax controversy is the exception rather than the rule. ${ }^{3}$ The Secretary acting

\footnotetext{
${ }^{1}$ Pronoun use convention: the report uses the feminine singular pronoun to refer to the taxpayer unless the taxpayer refers to an entity in which event the pronoun will be singular neuter.

${ }^{2}$ While courts may refuse to apply a regulation because it does not accurately interpret the Code, a court may refuse to apply a statute only if the statute conflicts with the United States Constitution.
}

Henry Ordower, Professor of Law

Saint Louis University School of Law

U.S. National Report: The Burden of Proof in Tax Matters $\quad$ Page 1 
through the Commissioner has the authority to settle with the taxpayer for less than the amount the government otherwise determines is the taxpayer's correct tax liability. ${ }^{4}$ The Commissioner delegates that settlement authority to Appeals, ${ }^{5}$ and, in matters under Chief Counsel's jurisdiction, to Chief Counsel. ${ }^{6}$ Appeals' stated mission is to settle civil tax controversies without litigation. ${ }^{7}$ Appeals determines the amount for which the government will settle based upon its evaluation of the "hazards of litigation." 8 In evaluating the "hazards of litigation" in contemplation of an administrative level settlement, Appeals analyzes the impact of the burden of proof rules among other factors such as legal precedents generally and in the taxpayer's venue of residence, ${ }^{9}$ available factual data, credibility of the taxpayer and other factors that a court would take into account in rendering a decision.

Under a "hazards of litigation" analysis, Appeals evaluates each issue and seeks to determine the likelihood of a government or taxpayer victory on each issue. If Appeals concludes that the taxpayer has a sixty percent chance of winning on that issue and the government forty percent, Appeals will offer to compromise the taxpayer's liability with respect to that issue on a 60-40 basis. If, for example, the amount in controversy on that issue is US\$100, Appeals would accept a US\$40 payment and close the issue.

The audit and examination function of the IRS does not have settlement authority. Following completion of an examination, the examiner sends the taxpayer a thirty day letter in which the examiner lists the proposed adjustments to the taxpayer's return. ${ }^{10}$ Within thirty days, the taxpayer may (i) agree to the changes and arrange to pay the additional tax, (ii) protest in writing to Appeals, thus moving the file from exam to Appeals for further discussion and possible settlement, or (iii) continue to disagree with the adjustment. If the taxpayer disagrees or does not respond, the IRS will issue a notice of deficiency and the taxpayer may petition the Tax Court to redetermine the deficiency before paying the additional tax. ${ }^{11}$ At examination level, the IRS may not compromise the taxpayer's liability for an amount less than the full amount it determines to be the correct tax. The examiner generally looks only at specific issues that have caused the taxpayer's return to become subject to the audit. The examiner has reasonably extensive discretion in accepting or refusing to accept the evidence in support of the taxpayer's reporting. That discretion is

\footnotetext{
${ }^{3}$ Public statements by IRS officials disclose that more than eighty percent of controversies settle without litigation.

${ }^{4}$ I.R.C. $\$ \$ 7121$ (closing agreements), 7122 (compromises).

${ }^{5}$ See Delegation Orders 60 and 66 at IRM 1.2.47.

${ }^{6}$ Rev. Proc. 87-24, 1987-1 C.B. 720 (describing the procedure for allocating settlement authority on docketed cases, that is, case in which the taxpayer has petitioned the Tax Court to redetermine a deficiency, see infra note 70 and accompanying text, between Appeals and Chief Counsel).

7 “.... appeals is the only administrative function of the Service with authority to consider settlements of tax controversies, and as such has the primary responsibility to resolve these disputes without litigation to the maximum extent possible. IRM 1.2.17 (policy statement on appeals function within the IRS).

8 “Appeals will ordinarily give serious consideration to an offer to settle a tax controversy on a basis which fairly reflects the relative merits of the opposing views in the light of the hazards which would exist if the case were litigated. However, no settlement will be made based upon nuisance value of the case to either party." IRM 1.2.17.1.6 Policy Statement 8-47 (Approved 04-06-1987).

${ }^{9}$ See discussion infra in Part III.A. for a discussion of venue and legal precedents.

${ }^{10}$ See discussion and Form 5701 for proposed settlements (available at http://www.irs.gov/businesses/article/0,,id=180776,00.html).

${ }^{11}$ I.R.C. $\$ 6212$ and see infra note 70.
}

Henry Ordower, Professor of Law

Saint Louis University School of Law

U.S. National Report: The Burden of Proof in Tax Matters 
comparable to but by no means identical to or sanctioned administratively as settlement authority.

B. Civil Matters: Taxpayer as Plaintiff. In United States jurisprudence, the plaintiff in a lawsuit bears the burden of proof. ${ }^{12}$ The taxpayer is the plaintiff in all civil tax proceedings (called the petitioner in the Tax Court) and initially bears the burden of proof as to both income and deduction. ${ }^{13}$ Unlike Sweden (as noted in the questionnaire for this project), the burden of proof is not a function of whether deduction or income is at issue. ${ }^{14}$

The taxpayer has better knowledge of the facts than does the government on both income and deduction. The taxpayer has an obligation to disclose those facts in her tax return and assess her own tax liability. ${ }^{15}$ The government's assessment of tax or notice of deficiency is presumptively correct. ${ }^{16}$ The taxpayer must introduce evidence to overcome that presumption in order to move to a preponderance of credible evidence determination of her liability in a court proceeding.

Under law in effect since $1998,{ }^{17}$ the taxpayer may shift the burden of proof to the government in a civil tax matter by producing credible evidence in support of her position. That same credible evidence would overcome the presumption that the government's assessment is correct. It is difficult to evaluate how much shifting the burden of proof adds to

${ }^{12}$ Wickwire v. Reinecke, 275 U.S. 101, 105 (1927) (estate tax determination that a gift was in contemplation of death and includable in the decedent's estate for estate tax purpose, the Court observing that the plaintiff bears the burden of proof).

${ }^{13}$ I.R.C. $\$ 7454$ (a) imposes the burden of proof on the IRS to the extent that the tax deficiency is on account of alleged fraud with intent to evade tax. Other exceptions to the general taxpayer burden of proof rules exist for foundation managers under I.R.C. $§ 7454(b)$ and transferees under I.R.C. $§ 6902$.

${ }^{14}$ Nevertheless, in Rockwell v. Commissioner, 512 F2d 882, 886 ( $9^{\text {th }}$ Cir., 1975) (holding that the issue of whether real property is held for sale to customers in the ordinary course of the taxpayer's business is a question of fact for the trier of fact), the court suggests that in an appropriate case and once the taxpayer overcomes the presumption of correctness of the IRS's notice of deficiency, see infra note 16 and accompanying text, the burden of proof or persuasion may shift to the government when the government claims the taxpayer has unreported income. In that instance, it might be particularly difficult for the taxpayer to prove the negative, but that was not the issue in the case.

${ }^{15}$ I.R.C. $\$ 6011$ requires a return from taxpayers liable for any tax. I.R.C. $\$ 6001$ imposes on taxpayers a requirement to keep records of income and expenditure for tax purposes. I.R.C. $\S 6012$ requires the annual filing of an income tax return. With limited exceptions for taxpayers who do not itemize deductions and have gross income of less than $\$ 10,000$ under I.R.C. $\$ 6014$, taxpayers must compute their own tax liability. Similar return filing requirements under I.R.C. $\S 6017$ apply to the self-employment tax, and the executor of a decedent's estate must file an estate tax return under I.R.C. §6018. Partnerships and other tax transparent entities must file information returns disclosing their income and deductions. I.R.C. $\$ 6031$ for partnerships and limited liability companies. I.R.C. $\S 6037$ for $\mathrm{S}$ corporations. Even entities generally exempt from tax must file returns. I.R.C. $\S 6033$.

${ }^{16}$ Welch v. Helvering, 290 US 111, 115 (1933) (holding an expenditure to be capital, rather than ordinary in nature and confirming that the IRS's assessment is presumptively correct).

${ }^{17}$ I.R.C. \$7491. Section 3001(a) of the Internal Revenue Service Restructuring and Reform Act of 1998 ("IRRA" in the following), PL 105-206 (July 22, 1998), added section 7491 to the Code. IRRA represents a nadir of respect for the IRS. In an anti-IRS furor, Congress included provisions that made IRS employees subject to dismissal for a variety of reasons, including taxpayer harassment, and opened the door to taxpayer complaints. Following passage of the legislation, there was a wave of complaints against IRS employees. Following investigation, almost all the complaints proved unfounded. Ability to shift the burden of proof was part of that anti-IRS furor but similarly turned out to have little impact on judicial outcomes as discussed below. On the other hand, this change in the law to permit shifting of the burden of proof may have had some impact on administrative settlements of tax liability. See supra in text following note 8 and empirical study discussion in text accompanying note 27 infra.

Henry Ordower, Professor of Law

Saint Louis University School of Law

U.S. National Report: The Burden of Proof in Tax Matters 
the removal of the government's presumption of correctness barrier. In order to shift the burden, the taxpayer must have (i) met her obligations to substantiate her reporting of tax items, (ii) maintained records as Title 26 of the United States Code (the taxation title) requires ${ }^{18}$ and (iii) cooperated with the IRS when it requested information, witnesses, documents, meetings and interviews. ${ }^{19}$ In instances in which the IRS has reconstructed an individual's, but not an entity's, income based on statistical evidence derived from unrelated taxpayers, the government now has the burden of proof. ${ }^{20}$ And the IRS has the burden to produce evidence initially, but does not bear the burden of proof automatically, with respect to penalties. ${ }^{21}$ In addition to the general opportunity to shift the burden of proof, a variety of special burden of proof rules apply. ${ }^{22}$ I will discuss some of them briefly in other parts of this report.

Burden of proof is significant only in tax controversies having material questions of fact. Many tax disputes reach the United States Tax Court on stipulated facts for resolution on matters of interpretation of the tax laws. Where factual issues are in dispute, those issues often are a matter of degree and not of a matter of whether or not liability exists. For example, the value of property frequently is at issue. Courts need not choose between the government's value and the taxpayer's value in those cases but may select and frequently do select a value within a range between the two asserted values. ${ }^{23}$ In those instances, both parties produce their evidence of value. Even in cases involving a determination of whether or not the taxpayer should have tax liability, ${ }^{24}$ courts decide on the basis of the preponderance of the evidence that both parties produce rather than on the basis of which party bears the burden of proof. It would be a rare case in which the evidence is so balanced that the court would use the burden of proof as a tie-breaker rule.

An empirical study from 2003 sought to ferret out the impact of the 1998 legislation on shifting the burden of proof ${ }^{25}$ both with respect to decisional outcomes and settlements of tax liability. ${ }^{26}$ The study proved inconclusive but did observe a decline in the number of cases going to Tax Court rather than settling. ${ }^{27}$ In addition, a recent analysis of a large number of decisions of the United States Tax Court ${ }^{28}$ discloses that the burden of proof is almost never decisive in civil tax matters. Rather the Tax Court decides almost every case on the preponderance of the evidence after both parties, the government and the taxpayer, have presented their cases.

\footnotetext{
${ }^{18}$ I.R.C. $\$ 6001$.

${ }^{19}$ I.R.C. $\$ 7491(\mathrm{a})(2)$.

${ }^{20}$ I.R.C. $\$ 7491(\mathrm{~b})$.

${ }^{21}$ I.R.C. $\$ 7491(\mathrm{c})$.

${ }^{22}$ For example, I.R.C. $\$ 534$ long has placed the burden of proof on the IRS in accumulated earnings tax cases in Tax Court if the taxpayer complies with specific procedural requirements.

${ }^{23}$ Turner v Commissioner, 13 T.C.M. (CCH) 462 (1954) (holding that the value of steamship tickets the taxpayer won to be the midpoint between the IRS's and the taxpayer's asserted values).

${ }^{24}$ Commissioner v. Duberstein, 363 US 278, 289 (1960) (holding that the trier of fact must determine on the basis of the "totality of the facts" whether or not a purported gift is gift for tax purposes and excludable from the recipient's income or not a gift and includable in income).

${ }^{25}$ See discussion supra in text accompany note 17.

${ }^{26}$ John R. Gardner and Benjamin R. Norman, Empirical Study: Effects of the Shift in the Burden of Proof in the Disposition of Tax Cases, 38 Wake Forest L.Rev. 1357 (2003).

${ }^{27}$ Id. at 1374 .

${ }^{28}$ Philip N. Jones, The Burden of Proof 10 Years after the Shift, 121 Tax Notes 287 (October 20, 1998) (analyzing burden of proof, burden of production, and the effect of I.R.C. §7491).
}

Henry Ordower, Professor of Law

Saint Louis University School of Law

U.S. National Report: The Burden of Proof in Tax Matters 
C. Collection and Criminal Proceedings. Once the IRS has assessed the tax, ${ }^{29}$ it must notify the taxpayer of the assessment, demand payment, ${ }^{30}$ and proceed to collect the assessed tax. Since 1998, there are statutory limitations on harsh collection methods and harassment which effectively limit the IRS in its collection efforts. ${ }^{31}$ When the IRS initiates a tax collection action or seeks court involvement in a levy, it becomes the plaintiff and bears the burden of proof. However, in collection cases neither the correctness of the tax assessment nor the application of substantive tax law is before the court. Taxpayers may defend against collection only on procedural grounds. The government does not have to prove that the assessment is correct but only that the government complied with the procedural rules for the assessment, notified the taxpayer at the correct time, and identified the taxpayer correctly. Taxpayers may not sue to prevent assessment or collection. ${ }^{32}$

Under limited circumstances where the government believes that the collection of the tax is in jeopardy, the notice of assessment and collection of the tax may coincide. ${ }^{33}$ The taxpayer may post a bond to prevent a levy on her property ${ }^{34}$ and may sue to prevent the levy. ${ }^{35}$ The IRS has the burden of proof as to the issue of the reasonableness of the jeopardy levy but not its amount. ${ }^{36}$ As long as the IRS provides a written statement describing the basis for its assessment, the taxpayer continues to have the burden of proof on the amount of the assessment. ${ }^{37}$

Similarly, the government has the burden of proof in criminal matters since it initiates the proceedings. The standard for criminal liability is higher than the preponderance of the evidence standard for civil proceedings. The government must prove beyond a reasonable doubt $^{38}$ that the individual it has charged criminally either willfully sought to evade or defeat a tax or willfully aided and abetted another in evading or defeating a tax. ${ }^{39}$ A criminal conviction is determinative on the issue of the taxpayer's civil liability. If the government has established beyond a reasonable doubt that the taxpayer willfully has underreported or underpaid her tax and is criminally liable, the government certainly has met the civil burden to establish the tax liability itself. The converse in not true, however. A criminal acquittal would not prevent the IRS from assessing underpaid taxes. Despite criminal acquittal, the assessment remains presumptively correct. The taxpayer would have to prove by a preponderance of the evidence that she was not liable for the tax or, if she manages to shift

\footnotetext{
${ }^{29}$ I.R.C. $\$ \$ 6201-03$.

${ }^{30}$ I.R.C. $\$ 6303$.

${ }^{31}$ I.R.C. $\$ 6304$, added to the Code by IRRA, supra note $17, \S 3466$ (a).

${ }^{32}$ I.R.C. $\$ 7421$, generally referred to as the anti-injunction act, prohibits courts from enjoining assessment and collections and forces taxpayers to follow the procedures for challenging assessments that the Code provides.

${ }^{33}$ I.R.C. $\S \S 6851,6861$. The taxpayer may stay collection of the jeopardy amount by posting bond. I.R.C. $\S 6863$ and also may commence an action under I.R.C. $§ 7429$. Under I.R.C. $§ 7429(\mathrm{~g})$,

${ }^{34}$ I.R.C. $\$ 6863(a)$.

${ }^{35}$ I.R.C. $\$ 7429$.

${ }^{36}$ I.R.C. $\$ 7429(\mathrm{~g})(1)$.

${ }^{37}$ I.R.C. $\$ 7429(\mathrm{~g})(2)$.

38 "Beyond a reasonable doubt" is a traditional formulation of the criminal liability standard of proof.

${ }^{39}$ United States v. Garber, 607 F.2d 92 (5th Cir. 1979) (acquittal under I.R.C. §7201 of willful evasion on failure to report income from sale of taxpayer's peculiar blood-type). Ch. 75 of the Code, I.R.C. $\$ 7201$ et seq. enumerates the various tax offenses.
}

Henry Ordower, Professor of Law

Saint Louis University School of Law

U.S. National Report: The Burden of Proof in Tax Matters 
the burden of proof to the IRS, ${ }^{40}$ the IRS would have to establish liability only by a preponderance of the evidence.

\section{Background on United States Federal Taxes}

Unlike the Member States of the EU, the United States imposes no general consumption tax. ${ }^{41}$ The United States does imposes a variety of excise taxes on specific types of property, including automotive fuel, ${ }^{42}$ communications, ${ }^{43}$ air transportation, ${ }^{44}$ gambling, ${ }^{45}$ alcohol, ${ }^{46}$ tobacco products, ${ }^{47}$, and even tires ${ }^{48}$ but no general sales or value added tax. Taxes raising the greatest amount of revenue in the United States are the income and wage-based taxes. The United States imposes an income tax on individuals, ${ }^{49}$ some corporate entities ${ }^{50}$ estates and some trusts. ${ }^{51}$ The partners in partnerships ${ }^{52}$ members of limited liability companies, ${ }^{53}$ shareholders of S corporations, ${ }^{54}$ grantors ${ }^{55}$ or beneficiaries of trusts ${ }^{56}$ include their shares of the entities' income in their individual incomes and the entities themselves are not subject to income tax. Social security ${ }^{57}$ and Medicare ${ }^{58}$ taxes take the form of either a split between the employer and employee or a self-employment $\operatorname{tax}^{59}$ on the self-employed. The United States also imposes a tax on gifts, other than charitable gifts, ${ }^{60}$ and on the estates of decedents, except decedents dying in $2010 .^{61}$ The IRS administers all the federal taxes and its determinations of the amount of a taxpayer's tax liability are

\footnotetext{
${ }^{40}$ I.R.C. $\$ 7491(\mathrm{a})$.

${ }^{41}$ There has been considerable discussion over the past 15-20 years in the academic, economic and professional literature suggesting that the U.S. should shift to a broad consumption-based income tax or a national sales or value added tax. See, generally, Edward J. McCaffery, Federal Tax Policy in the New Millennium: The Missing Links in Tax Reform, 2 Chap. L. Rev. 233 (1999) and cited material.

42 I.R.C. $\$ 4081$.

${ }^{43}$ I.R.C. $\$ 4251$.

${ }^{44}$ I.R.C. $\$ 4261$.

${ }^{45}$ I.R.C. $\$ 4401$.

${ }^{46}$ I.R.C. $\$ 5001$ et seq.

${ }^{47}$ I.R.C. $\$ 5701$.

${ }^{48}$ I.R.C. $\$ 4701$.

${ }^{49}$ I.R.C. §1(a)-(d).

${ }^{50}$ I.R.C. $\$ 11$.

${ }^{51}$ I.R.C. $\$ 1(\mathrm{e})$.

${ }^{52}$ I.R.C. $\$ 701$.

${ }^{53}$ Id. Treas. reg. $\S 301.7701-2(\mathrm{c})(1)$ treats limited liability companies as partnerships and their members as partners for tax purposes.

${ }^{54}$ I.R.C. \$1363(a) (S corporation not subject to tax); I.R.C. \$1366(a) (shareholders of S corporation include their shares of corporate income).

${ }^{55}$ I.R.C. $\$ 671$.

${ }^{56}$ I.R.C. $\$ \S 641,651$.

${ }^{57}$ I.R.C. $\$ 3101$ (a) (employee's share of retirement savings tax); I.R.C. §3111(a) (employer's share).

${ }^{58}$ I.R.C. $\$ 3101(\mathrm{~b})$ (employee’s share of hospitalization tax); I.R.C. §3111(b) (employer's share).

${ }^{59}$ I.R.C. \$1401(a) (retirement), (b) (hospitalization).

${ }^{60}$ I.R.C. $\$ 2501$; I.R.C. $\$ 2522$ (deduction for charitable gifts).

${ }^{61}$ I.R.C. $\$ 2001$. Owning to temporary tax reductions in 2001 legislation, the estate tax was repealed for calendar year 2010 but, absent Congressional action, will become effective again at the rates in effect in 2001 for decedent's dying after 2010. Section 501(a) of the Economic Growth and Tax Relief Reconciliation Act of 2001, PL 107-16 (June 7, 2001) added I.R.C. $\$ 2210$ terminating the Estate Tax for the estates of decedent's dying after 2009. However, the sunset provision of the 2001 Act, section 901 of that Act caused all provisions of the Act relating to the estate tax to cease to apply after 2010, thereby restoring the Estate Tax to its 2001 form.
}

Henry Ordower, Professor of Law

Saint Louis University School of Law

U.S. National Report: The Burden of Proof in Tax Matters 
presumptively correct for all those taxes. The taxpayer must initiate proceedings to contest the IRS's determination and initially carries the burden of proving that the IRS is incorrect.

\section{Litigation Forums -- Procedural Background}

A. Court Jurisdiction in Civil Tax Matters. If the taxpayer is unable to settle with the IRS on the amount of her tax liability or chooses not to go to Appeals, ${ }^{62}$ she may initiate civil litigation in one of three forums: the Tax Court, ${ }^{63}$ the Court of Federal Claims, ${ }^{64}$ or the United States District Court for the district where the taxpayer lives or, in the case of an entity, where the entity's principal place of business is located. ${ }^{65}$ The choice of forum is strategic. In Tax Court, the taxpayer need prove only that the government's determination of liability is incorrect. ${ }^{66}$ In refund suits in the Court of Federal Claims and the United States District Courts, the taxpayer also has to prove the correct amount of tax. ${ }^{67}$ In addition, each forum may have its own set of legal precedents that impact the outcome of the case and, concomitantly, determination of the significance of allocation of the burden of proof to the case.

Despite the opportunity for strategic choice of forum, most often limitations on the taxpayer's resources or simple unwillingness to pay the tax in advance of the litigation drive the taxpayer to choose the Tax Court. Taxpayers may litigate in the Tax Court without first having paid their tax in full ${ }^{68}$ so that the Tax Court hears the bulk of tax cases. If the taxpayer is willing to pay her tax before litigating, the taxpayer may sue for a refund either in the Federal District Court having jurisdiction or in the Court of Federal Claims that has general jurisdiction over monetary claims against the United States. ${ }^{69}$ In the applicable Federal District Court, the taxpayer may demand a jury trial, rather than a bench trial, to determine issues of fact and to apply the facts to the law based upon the judge's instructions as to the law.

\footnotetext{
${ }^{62}$ Appeals does not automatically review the result of an taxpayer examination. The taxpayer must protest the proposed deficiency and request Appeals. Many taxpayers are unfamiliar with the Appeals function or, if familiar, prefer not to take their disagreement with the IRS to another IRS department even if it is independent. ${ }^{63}$ The United States Tax Court is an administrative court that the legislature established under Article I of the United States Constitution. I.R.C. §7441. The Tax Court has jurisdiction only in tax matters. It has no criminal jurisdiction and there are other matters over which it has no jurisdiction even related to tax. Judges of the Tax Court have fifteen year terms, often renewed.

${ }^{64} 28$ USCS $\$ 1491$ gives the Court of Federal Claims jurisdiction over claims against the United States. The Court has 16 judges whom the President appoints to 15 year terms. See, generally, the Court's online brochure available at http://www.uscfc.uscourts.gov/sites/default/files/court_info/Court_History_Brochure.pdf.

${ }^{65} 28$ USCS $\S 1346$. If the taxpayer elects to proceed in the District Court, $28 \overline{\text { USCS }} \S 1 \overline{4} 02$ places jurisdiction in the District Court where the taxpayer resides or, in the case of an entity, where its principal place of business is located. Unlike the Tax Court, the Federal District Courts are established under the judiciary Article III of the United States Constitution. The Federal District Courts are courts of general jurisdiction and the judges on those courts enjoy lifetime tenure so that they may render their decisions objectively and free from any possible outside political or social influence.

${ }^{66}$ Welch v. Helvering, 290 US 111, supra note 16.

${ }^{67}$ U.S. v General Dynamics, 481 US 239 (1987) (taxpayer must prove entitlement to a tax benefit); Eli Lilly Co. v. U.S., 372 F2d 990 (Ct.Cl. 1967) (taxpayer must prove there was an actual overpayment of tax). See, generally, Theodore D. Peyser, Refund Litigation, 631-3d T.M. Portfolio A-53 (2006, 2010).

${ }^{68}$ Various special rules enable the taxpayer under some circumstances to pay the tax attributable to a transaction or part of an assessment in order to gain access to other forums.

${ }^{69}$ Supra notes 64 and 65.
}

Henry Ordower, Professor of Law

Saint Louis University School of Law

U.S. National Report: The Burden of Proof in Tax Matters 
Generally, the IRS must send the taxpayer a notice of deficiency when it determines that the taxpayer has underpaid her tax. ${ }^{70}$ The notice of deficiency, otherwise known as a ninety day letter, gives the taxpayer ninety business days in which to petition the Tax Court to redetermine the deficiency. ${ }^{71}$ The notice of deficiency -- with limited exceptions for mathematical and clerical errors, fraud, change in treatment of itemized deductions, among other exceptions -- precludes further notices of deficiency once the taxpayer files a petition in Tax Court. Following the ninety day period, the IRS may assess the tax and proceed to collect it.

The taxpayer may pay any additional tax following an examination, even before the examiner issues a thirty day letter. ${ }^{72}$ Similarly, the taxpayer may pay the additional tax on the basis of the deficiency letter or before the IRS issues the deficiency letter. An express assessment does not have to precede the tax payment. ${ }^{73}$ If the taxpayer pays the tax, the taxpayer may file a claim for overpayment of tax as long as the statute of limitations for refund claims has not elapsed. The statute of limitations is generally three years from the date the return for the year was first due, six years for substantial understatements of the taxpayer's gross income. ${ }^{74}$ When the IRS denies the claim for refund or fails to respond to the claim for refund within six months, the taxpayer then may sue for a refund of the overpayment of tax in the Court of Federal Claims or the District Court. ${ }^{75}$

While tax law primarily is statutory in the United States, judicial decisions play a significant role in interpreting and applying the statutes. In addition, numerous judicial doctrines limiting or expanding the reach of statutes have developed over the years. ${ }^{76}$ Until 2010, the United States did not have a general anti-avoidance statute but did have a judicial economic substance doctrine that the courts applied in a manner quite like a general antiavoidance rule. ${ }^{77}$ The economic substance doctrine became statutory as a revenue raising provision in the 2010 health care legislation. ${ }^{78}$

\footnotetext{
${ }^{70}$ I.R.C. $\$ 6212$ (a). See, however, the exception for jeopardy assessments in I.R.C. $§ 6861$.

${ }^{71}$ Taxpayers who are outside the United States when the IRS issues the letter may get 150 days to respond and petition the Tax Court. Unlike the claims for refund in the Court of Claims or District Court, the action is technically not a lawsuit against the United States although it has the same effect. As the taxpayer/petitioner typically will not recover money from the U.S. upon a successful Tax Court petition, the Tax Court's judgment fixes the amount that the taxpayer will have to pay and, when favorable to the taxpayer, resembles a declaratory judgment that the taxpayer has no liability. I.R.C. $\$ 7430$ provides for the U.S. to pay the taxpayer's costs and legal fees if the U.S.'s position in the litigation was not substantially justified.

${ }^{72}$ See supra note 10 and accompanying text for the thirty day letter.

${ }^{73}$ I.R.C. $\$ 6201$

${ }^{74}$ I.R.C. $\$ 6501$ (general statute of limitations); I.R.C. $§ 6501(\mathrm{e})$ (substantial omission of items). If the taxpayer commits fraud, there is no statute of limitation for the assessment of tax.

${ }^{75}$ I.R.C. $\$ 7422$.

${ }^{76}$ For example, Lucas v. Earl, 281 US 111 (1930), established that the contractual assignment of half the taxpayer's income from his services to his spouse would not result in the spouse, rather than the taxpayer being taxed on the income despite the absence of any statute to that effect.

${ }^{77}$ See, generally, on the economic substance doctrine as a general anti-avoidance rule, Henry Ordower, The Culture of Tax Avoidance, 55 Saint Louis U. L. Rev. (2010 forthcoming) (draft as Saint Louis U. Legal Studies Research Paper No. 2010-06 available at

http://papers.ssrn.com/sol3/papers.cfm?abstract id=1596684\#\#), (discussing various judicial doctrines in the context of tax shelters and the issues of general anti-avoidance rules); Tracy A. Kaye, The Regulation of Corporate Tax Shelters in the United States, 58S AM.J.COMP. L. 583 (2010) (a national report on corporate tax shelters for the IACL quadrennial meeting and considering the effect of the new statute on the doctrine), Leandra Lederman, W(h)ither Economic Substance?, 95 IOWA L. REV. 389 (2010) (addressing the
}

Henry Ordower, Professor of Law

Saint Louis University School of Law

U.S. National Report: The Burden of Proof in Tax Matters 
In addition to developing general doctrines applicable in the absence of statutes, court intervention often is essential to interpretation of statutes. Statutes frequently are ambiguous and their applications to specific factual situations uncertain. While treasury regulations or administrative rulings resolve the ambiguity and uncertainty on many occasions, in other instances taxpayers disagree with the administrative application of the statutes to the facts even where the taxpayer and the government do not disagree on the facts themselves. The courts are left to resolve the disagreements. Courts in turn apply the common law doctrine of stare decisis ${ }^{79}$ when they have confronted similar issues in the past. Under common law doctrine, ${ }^{80}$ lower courts generally follow their own precedents where there is no judicial precedent from the appellate court to which an appeal of the case before the lower court lies unless they find the decision of another trial or appellate court more persuasive than their own precedents. Trial courts customarily apply the judicial rulings of the appellate court to which an appeal would lie, lest the appellate court, applying its own precedent, overturn the trial court's decision. If no precedent exists in the trial court or its appellate target, it will look to all other courts and may rely on other precedents. If the case is one of first impression so that no precedent exists, a trial court will interpret the law based upon its reading of the statutes, regulations, administrative rulings, and legislative history.

There are no specialty courts of appeals for tax matters in the United States. ${ }^{81}$ Decisions of the courts in tax matters are appealable to the Circuit Courts of Appeals and, ultimately, on certiorari ${ }^{82}$ to the United States Supreme Court. The Circuit Courts of Appeals are general jurisdiction appellate courts. Appeal from decisions of the Tax Court and the District Courts lies to the Court of Appeals for the judicial circuit in which the taxpayer resides and, in the case of an entity, where the entity has its principal place of business. The Tax Court even may decide similar cases inconsistently with one another because appeal in those cases lies to different Courts of Appeals that offer inconsistent precedents. ${ }^{83}$ Appeal from decisions of the Court of Federal Claims lies to the Court of Appeals for the Federal Circuit in Washington D.C.

development of the doctrine), Joseph Bankman, The Economic Substance Doctrine, 74 S CAL L REV 5 (2000) (identifying flaws and complexities of the dual economic substance test and recommending an ordinary course of business exception).

${ }^{78}$ Section 1409(a) of the Health Care and Education Reconciliation Act of 2010, PL 111-152 (March 30, 2010) added subsection (o) to I.R.C. $§ 7701$.

79 "Latin for 'to stand by things decided.' Stare decisis generates the doctrine of precedent. Courts cite to stare decisis when an issue has been previously brought to the court and a ruling already issued." LII Legal Information Institute at Cornell University, Wex (available at: http://topics.law.cornell.edu/wex/stare_decisis).

${ }^{80}$ Like the United Kingdom and unlike most jurisdictions in the remainder of Europe (Germany and the

Scandinavian countries having developed arguably into hybrid civil/common law systems), the U.S. and all its states except Louisiana are common law jurisdictions.

${ }^{81}$ There has been considerable discussion of the need for a separate trial and appellate court branch for the tax specialty, but Congress never has considered seriously creating that system. See, for example, Martin D.

Ginsburg, The Federal Courts Study Committee on Claims Court Tax Jurisdiction, 40 Cath. U.L. Rev. 631 (1991), in which Professor Ginsburg argued compellingly for the creation of a separate court of appeals for tax matters to assure consistency in tax jurisprudence and fairness to taxpayers and the government alike.

${ }^{82}$ Certiorari is a discretionary form of jurisdiction. The Supreme Court is not obliged to hear any tax appeals but may accept or refuse to hear a case at its discretion, usually exercised at the election of five or more of its nine justices.

${ }^{83}$ Golson v. Commissioner, 54 TC 742 (1970) (holding a payment to be for insurance, not interest, the court stating that it is obliged to follow the appellate precedent of the court to which any appeal would go).

Henry Ordower, Professor of Law

Saint Louis University School of Law

U.S. National Report: The Burden of Proof in Tax Matters 
B. State Taxes. Further complicating tax jurisprudence in the United States and in limited instances the allocation of the burden of proof is the independent taxing power of the states and the states' underlying political subdivisions which also may have independent taxing authority. With the exception of tariffs for which the states have no authority, each state of the United States, like each Member State of the EU, has both taxing jurisdiction and collection authority within its geographic territory. Unlike the EU that lacks central taxing and collection authority, a state's taxing and collection authority is separate from and coextensive with the central authority of the United States. Moreover, the states and their political subdivisions may structure and collect their taxes without regard to the risk that taxes in the state may duplicate a federal tax or taxes in other states.

Most states and their political subdivisions rely on some combination of sales taxes, real and personal property taxes and income taxes. Each state has its own taxing authority and even though their taxing power is derivative of the state in which they are located, many political subdivisions have separate taxing authorities. While Congress enacts federal taxes with the agreement of the President of the United States, state legislatures, sometimes city councils and the governing board or authority of other governmental units have general power to enact taxes. Increasingly, however, state constitutions require a referendum of voters in order to enact or increase any tax. ${ }^{84}$ In the case of ad valorem taxes like property taxes, the state or local taxing authority determines the value of the taxpayer's taxable property and assesses the tax. The state or local tax authority can observe real property but, with the exception of licensed property such as vehicles, has to rely on the taxpayer to report the personal property she owns. Determination and collection of other taxes, including sales taxes and income taxes, depend upon the taxpayer's self-assessment.

As with IRS determinations of tax liability, the decisions of those state and local taxing authorities are presumptively correct. Also like the IRS, state and local taxing authorities are willing and interested in settling tax disagreements without formal administrative hearings or trials. Taxpayers wishing to challenge the state or local tax authority's determinations often must petition the state or local tax commission first for an administrative, evidentiary hearing before appealing to a state court of competent jurisdiction. Taxpayers initially bear the burden of proof in those hearings although, as a practical matter, the state or local tax authority and the taxpayer both present their evidence and the administrative or judicial tribunal most often decides the tax issue on the preponderance of the evidence. Many of the cases determine matters of valuation and the tribunal may choose a value anywhere within the range of values that the taxpayer and the state taxing authority present, so that the burden of proof has minimal significance.

\section{Specific Burden of Proof Rules}

\section{A. United States National Concepts. ${ }^{85}$}

\footnotetext{
${ }^{84}$ For example, Proposition 13, enacted by referendum in California in June, 1978, added Article IIIA to the California Constitution. Proposition 13 limited property taxes and subjected any increase in property tax over a certain minimum to a vote of the people. Similarly, the Hancock amendment in 1980 added $\S 18$ to Mo. Const. Art. X and subjected all tax increases in excess of certain minimal permissible increases to a vote of the people. ${ }^{85}$ The following discussion ties more directly into the questionnaire that Gerard Meussen, Klaus-Dieter Drüen, Börje Leidhammar, and Giuseppe Marino prepared for the 2011 EATLP Conference in Uppsala, Sweden.
}

Henry Ordower, Professor of Law

Saint Louis University School of Law

U.S. National Report: The Burden of Proof in Tax Matters 
1. General rule. The foregoing discussion outlines the general burden of proof rules in the United States. To summarize, the taxpayer initially bears the burden of proof in all civil tax proceedings in which the taxpayer contests her liability for the tax or the amount of the tax. The IRS's determination of both obligation for and amount of the tax is presumptively correct. An amendment to the Code in $1998^{86}$ enabled the taxpayer to shift that burden of proof to the government by presenting credible evidence in her favor and complying with some procedural requirements. ${ }^{87}$ Position of the burden of proof is the same whether the matter at issue is income or deduction and whether the taxpayer is in an administrative proceeding or in court. In those instances, however, in which the IRS determines the taxpayer's tax liability solely based upon statistical information from unrelated taxpayers, the government bears the burden of proof as to the income amount in any court proceeding. ${ }^{88}$ Courts rule based upon the preponderance of the evidence. Burden of proof is rarely decisive in the outcome of civil tax litigation.

Penalties and Additions to Tax. Under the Code, the government bears the burden of proof on some of the penalties. ${ }^{89}$ Among those penalties are those the Code imposes on promoters of arrangements that facilitate underreporting by others, captioned in the Code as the Promoting Abusive Tax Shelter, etc.," 90 penalties for aiding the understatement of tax by others, ${ }^{91}$ and penalties for filing frivolous returns and submitting frivolous tax information. ${ }^{92}$ More generally, where penalties relate to fraudulent activities, ${ }^{93}$ the government has the burden of proof. Judicial decisions set that burden at clear and convincing evidence that some portion of the tax underpayment is attributable to the fraud. ${ }^{94}$

Burden of Production: Expatriation; Penalties and Additions to Tax. If the government "establishes that it is reasonable to believe that an individual's loss of United States citizenship would, ..., result in a substantial reduction for the taxable year in the taxes on his probable income for such year, the burden of proving for such taxable year that such loss of citizenship did not have for one of its principal purposes the avoidance of taxes ... shall be on such individual." "In this instance, the government would have to demonstrate that reasonable assumptions about the taxpayer's income would subject the taxpayer to a greater United States tax if the taxpayer were subject to tax as a citizen or resident rather than as a non-resident alien. In addition, since 1998, the government generally bears the burden of

\footnotetext{
${ }^{86}$ I.R.C. $\$ 7491$.

${ }^{87}$ See supra note 17 and accompanying text.

${ }^{88}$ I.R.C. $\$ 7491($ b).

${ }^{89}$ I.R.C. $\$ 6703$ imposes the burden of proof for penalties under I.R.C. $\S 6700, \S 6701$ and $\S 6702$ arising from (i) providing others with information that causes those others to understate their tax liability and (ii) taking frivolous positions in reporting to the government.

${ }^{90}$ I.R.C. $\$ 6701$.

${ }^{91}$ I.R.C. $\$ 6701$.

92 I.R.C. $\$ 6702$.

${ }^{93}$ I.R.C. $\$ 6663($ b), I.R.C. $\$ 7454$ (a) (on burden of proof in fraud cases).

${ }^{94}$ For example, Akland v. Commissioner, 767 F.2d 618, 621 (9th Cir. 1985) (holding sufficiently clear and convincing evidence in the taxpayer's use of foreign trusts to conclude that some portion of the understatement was due to fraud). The court states: "the Commissioner must prove fraud by clear and convincing evidence, I.R.C. $§ 7454(a)$; Stone v. Commissioner, 56 T.C. 213, 220 (1971), but intent can be inferred from strong circumstantial evidence, Spies v. United States, 317 U.S. 492, 499, 87 L. Ed. 418, 63 S. Ct. 364 (1943).” ${ }^{95}$ I.R.C. $\S 877$ (f). I.R.C. $\S 877$ generally subjects expatriating U.S. citizens and permanent residents to a continuing worldwide taxation for 10 years after expatriation to avoid tax.
}

Henry Ordower, Professor of Law

Saint Louis University School of Law

U.S. National Report: The Burden of Proof in Tax Matters 
production as to tax penalties and other additions to tax. ${ }^{96}$ The burden of production differs from the burden of proof in that it obligates the government to introduce sufficient evidence to create a prima facie case for the taxpayer's liability before the taxpayer must introduce her evidence. The burden of production removes the presumption of correctness that generally attaches to the government's determination of tax liability. Burden of production has little impact on outcome since the government almost invariably has some credible evidence sufficient to support its notice of deficiency or assessment.

Miscellaneous, Non-Criminal Burden of Proof Shifts. Several provisions of the Code, some judicial decisions, or court rules impose the burden of proof upon the government or permit the taxpayer to shift the burden of proof to the government by presenting some evidence or authority for her position. Some of those provisions follow:

i) Foundation Managers. The government has the burden of proof that a foundation manager knowingly has participated in an act of self-dealing that the private foundation rules prohibit. ${ }^{97}$ As with fraud penalties that are a function of the taxpayer's knowledge or intent, the government bears the burden of proving that knowledge or intent. ${ }^{98}$

ii) Transferee Liability. Certain transferees of property from a taxpayer from whom or which the government is unable to collect a tax are liable for payment of that taxpayer's tax. ${ }^{99}$ In those instances, the government has the burden to prove in any proceedings before the Tax Court that the petitioner is liable as a transferee, but the government does not have the burden to prove the taxpayer's, rather than the transferee's, liability for the tax itself. ${ }^{100}$ The taxpayer still has the burden of proof on the liability itself. Tax Court would be the likely venue since someone denying transferee liability would seem unlikely to pay another's tax and then claim a refund. The refund route is available although quite risky. ${ }^{101}$ The purported transferee might have no refund claim for paying another's tax if the payer was not actually a transferee since the refund claim is derivative of the actual taxpayer having primary liability. ${ }^{102}$ Further, the statutory shift to the government of the burden to prove transferee liability is inapplicable.

iii) New Issue not Part of the Deficiency Notice. Under the Tax Court's own procedural rules, if the government raises an issue in Tax Court that it did

\footnotetext{
${ }^{96}$ I.R.C. $\$ 7491(\mathrm{c})$.

${ }^{97}$ I.R.C. $\$ 7454($ b). See I.R.C. $\$ 4941$ defining acts of self-dealing for private foundations.

${ }^{98}$ I.R.C. $\$ 6663(\mathrm{~b})$.

${ }^{99}$ I.R.C. $\$ 6901$.

${ }^{100}$ I.R.C. $\$ 6902(a)$.

${ }^{101}$ Campbell Farming Corp. v. United States, 132 F.Supp. 216, 132 Ct. Cl. 341 (Ct. Cl. 1955), (holding an actual transferee has a derivative refund claim).

${ }^{102}$ In Stahmann v. Vidal, 305 U.S. 61, 66 (1938), the Supreme Court held that a farmer was entitled to sue to recover a tax on cotton collected from the ginner of the cotton - the opposite situation of a transferee seeking to collect a tax paid as transferee. The Supreme Court observed: "[w] hether or not the tax was imposed upon the petitioners, they are, according to accepted principles, entitled to recover unless they were volunteers, which they plainly were not because they paid the tax under duress of goods."
}

Henry Ordower, Professor of Law

Saint Louis University School of Law

U.S. National Report: The Burden of Proof in Tax Matters 
not address in its deficiency notice, ${ }^{103}$ the government has the burden of proof on that issue. ${ }^{104}$

iv) Mitigation of limitations. In order to prevent injustice, the mitigation of limitations provision of the Code enables the taxpayer or the government to claim an adjustment even in an otherwise closed year. ${ }^{105}$ Under that provision, if as the result of a court determination or a settlement with the IRS, a taxpayer correctly excludes an item from income or claims a deduction, and the taxpayer should have included the item in income in an earlier year or the taxpayer erroneously claimed the same deduction in an earlier year, the government may reopen the closed year with respect to that item. The government bears the burden to prove that mitigating the limitations period for the item is appropriate. Alternatively, the taxpayer bears the burden of proof on mitigation if she wishes to reopen an earlier year and claim a deduction or exclude an item from income that she erroneously failed to deduct in the correct earlier year or erroneously included in income in the closed year. ${ }^{106}$

v) Accumulated Earnings Tax on Corporations. The United States imposes an income tax on the income of corporations, ${ }^{107}$ other than $\mathrm{S}$ corporations. ${ }^{108}$ Dividend distributions a corporation pays to its shareholders are includable in the shareholders' income. ${ }^{109}$ In order to defer or eliminate the tax on dividends, corporations occasionally accumulate their earnings beyond their business needs for accumulation of the earnings. The accumulation increases the value of the corporate shares, so that the shareholders might reap the benefit of that increase when they sell their shares. Sale of the corporate shares frequently is long term capital gain. For most of United States income tax history, long term capital gain has been subject to a lower rate of tax than have been corporate dividends. ${ }^{110}$ In order to prevent that dividend avoidance, there is a rarely imposed tax on a corporation's unreasonable accumulation of earnings. ${ }^{111}$ In Tax Court, the government bears the burden of proof as to the unreasonableness of the

\footnotetext{
${ }^{103}$ I.R.C. $\$ 6212(a)$, see discussion supra in text accompany note 70

${ }^{104}$ Tax Court Rule 142(a) (procedural rule).

${ }^{105}$ I.R.C. $\$ 1311$. As noted above, supra note 74 and accompanying text, generally a three year statute of limitations applies and closes the tax year from further amendment or examination adjustment. I.R.C. $\$ 6501$.

${ }^{106}$ Rev. Rul. 55-474 (I.R.S. 1955) (with respect to an earlier statute, holding the burden of proof rests upon the party claiming applicability of the exception the statute provides).

${ }^{107}$ I.R.C. $\$ 11$.

${ }^{108}$ I.R.C. $\$ 1361$, see supra note 54 and accompanying text for a brief description of S corporations as tax transparent entities.

${ }^{109}$ I.R.C. $\$ 301$. Until the end of 2010 , certain corporate dividends are subject to a maximum income tax rate in the hands of their individual, rather than corporate, shareholders of fifteen percent rather than the normal maximum rate of tax of 35 percent (also scheduled to revert to 39.6 percent at the end of 2010). I.R.C.

$\S 1(\mathrm{~h})(11)$. That provision is scheduled to terminate at the end of 2010 , so that the maximum rate of tax on dividends would become 39.6 percent. See note 61 supra.

${ }^{110}$ The current manifestation of that lower rate is the maximum fifteen percent rate for net capital gain in I.R.C. $\S 1(\mathrm{~h})$ (not scheduled to terminate at the end of 2010). Net capital gain is the excess of net long term capital gain over net short term capital loss. See definitions in I.R.C. $§ 1222$. Long term is more than one year.

${ }^{111}$ I.R.C. $\$ 531$.
}

Henry Ordower, Professor of Law

Saint Louis University School of Law

U.S. National Report: The Burden of Proof in Tax Matters 
accumulation if (i) it fails to notify the taxpayer in advance that it intends to impose the tax or (ii) following that notice, the taxpayer provides a statement specifying the reasons for the accumulation and sufficient facts to show the basis for the accumulation. ${ }^{112}$

vi) Restricted Property Formulaic Valuation. A taxpayer who receives property as compensation must include the fair market value of the property in her income. ${ }^{113}$ A permanent restriction that prohibits the taxpayer from selling the property except pursuant to a specific value formula (and usually for such restrictions) to a specific person tends to fix the value of the property. If the government determines that the value under the formula is incorrect because the restriction is not in fact applicable, the government bears the burden to prove the formula does not fix the value for purposes of the taxpayer's inclusion in income. ${ }^{114}$

Burden of Proof -- Beyond Reasonable Doubt: Criminal Prosecutions. The government bears the burden to prove beyond a reasonable doubt that the taxpayer is guilty of a tax crime. Conviction of a tax crime generally is determinative of civil liability, but acquittal does not eliminate civil tax liability because of the difference in the burden of proof. The United States' court system is unified and has no separate criminal courts. The Tax Court and the Court of Federal Claims are not courts of general jurisdiction and have no jurisdiction to try criminal cases. Both courts entertain civil tax disputes as do federal courts of general jurisdiction.

2. Burden of proof variations dependent on time or quality of self-reporting. Under United States law and without regard to extensive third party information reporting requirements, the United States requires self-reporting and self-assessment of tax liability. ${ }^{115}$ Since self-reporting always is required, the taxpayer's voluntary reporting has no effect on the burden of proof.

The general statute of limitations in tax matters is three years from the date the taxpayer files the required return of tax, or, if later, the last day on which the return could have been filed on time. ${ }^{116}$ Accordingly, if the taxpayer fails to file a return, no statute of limitations precludes later assessment and collection of tax even if the IRS files a return for the taxpayer under the authority it has to prepare returns for non-compliant taxpayers. ${ }^{117}$ The taxpayer carries the burden of proof until a statute of limitations bars further assessment. ${ }^{118}$

Similarly, no statute of limitations applies if the taxpayer files a false or fraudulent return with the intent to evade tax. ${ }^{119}$ As in other instances in which the taxpayer's intent is at issue, the government bears the burden of proof with respect to fraud or intent to evade

\footnotetext{
${ }^{112}$ I.R.C. $\$ 534$

${ }^{113}$ I.R.C. $\$ 83(\mathrm{a})$.

${ }^{114}$ I.R.C. $\$ 83(\mathrm{~d})$.

${ }^{115}$ I.R.C. $\$ 6011$ (returns of tax), I.R.C. $\$ 6001$ (maintenance of records). See supra note 15.

${ }^{116}$ I.R.C. $\$ 6501(\mathrm{a}),(\mathrm{b})$.

${ }^{117}$ I.R.C. $\$ 6020$.

${ }^{118}$ See supra note 12 and accompanying text.

${ }^{119}$ I.R.C. $\$ 6501(\mathrm{c})$.
}

Henry Ordower, Professor of Law

Saint Louis University School of Law

U.S. National Report: The Burden of Proof in Tax Matters 
tax. ${ }^{120}$ Moreover, the burden of proof of intent is by clear and convincing evidence, a higher burden of proof threshold than the standard preponderance of the evidence burden in civil matters but not so high as the threshold of beyond a reasonable doubt necessary to prove criminal fraud. ${ }^{121}$

If the taxpayer omits an amount in excess of twenty-five percent of the amount she actually reports on the return required of her gross income ${ }^{122}$ gross estate (executor reporting) ${ }^{123}$ amount of gifts, ${ }^{124}$ or excise tax liability, ${ }^{125}$ or fails to report income from an undisclosed financial account, the statute of limitations is six years rather than the standard three years. ${ }^{126}$ While the case law consistently states that the government has the burden to prove the substantial omission, ${ }^{127}$ other cases do not seem to shift the burden to the government. ${ }^{128}$ As a practical matter, the government will not rely on its assessment but will produce evidence, and the courts tend to evaluate that evidence in determining whether or not to extend the statute. If the government produces credible evidence, the taxpayer will have to refute that evidence and, in that respect will have the burden of proof. This seems to be one of the areas in which the burden to produce evidence falls first on the government but the burden of proof on the taxpayer. ${ }^{129}$

There is also an opportunity to mitigate the statute of limitations to prevent double inclusion, exclusion, or deduction. The party asserting mitigation has the burden of proof. ${ }^{130}$

3. Estimates and discretionary decisions. When the IRS estimates an individual taxpayer's income based upon statistical information from unrelated taxpayers, the government has the burden of proof. ${ }^{131}$ In all other instances, the general burden of proof rules apply. With some exceptions noted elsewhere, the taxpayer bears the burden of proof since the determination of the IRS is presumptively correct.

The IRS has no specific discretion at examination although tax examiners have implicit discretion to weigh factual material the taxpayer provides. Appeals has considerable discretion to evaluate the "hazards of litigation" in compromising the taxpayer's liability. ${ }^{132}$

\footnotetext{
${ }^{120}$ Griffiths v. Commissioner, 50 F.2d 782 (7th Cir. 1931)(holding that since the taxpayer did not prepare his own return, the government had not carried its burden to show fraud to extend the statute of limitations).

${ }^{121}$ Moore v. Commissioner, 619 F.2d 619 (6th Cir. 1980) (affirming a Tax Court decision and acknowledging that the clear and convincing evidence standard even if proved circumstantially).

${ }^{122}$ I.R.C. $\$ 61$ is the basic starting point for computation of taxable income and income tax liability and includes "all income from whatever source derived."

${ }^{123}$ I.R.C. $\$ 2031$.

${ }^{124}$ I.R.C. $\$ 2501$.

${ }^{125}$ Subtitle D of the Code, I.R.C. $\S \S 4001$ et seq.

${ }^{126}$ I.R.C. $\$ 6501(\mathrm{e})$.

${ }^{127}$ Bardwell v. Commissioner, 38 T.C. 84, 92 (T.C. 1962), affd. 318 F.2d 786 (10th Cir. 1963) (government met the burden of proof); Reeves v. Commissioner, T.C. Memo 1979-41 (T.C. 1979) (government failed to prove substantial omission).

${ }^{128}$ Basile v. Comm'r, T.C. Memo 2005-51 (2005) (well-pleaded facts suffice where taxpayer does not produce evidence to the contrary).

${ }^{129}$ See discussion supra at note 95 and accompanying text on expatriating taxpayers.

${ }^{130}$ I.R.C. $\$ 1311$ and discussion supra in text accompanying note 105 supra.

${ }^{131}$ I.R.C. $\$ 7491(b)$.

${ }^{132}$ Supra note 4 and accompanying text.
}

Henry Ordower, Professor of Law

Saint Louis University School of Law

U.S. National Report: The Burden of Proof in Tax Matters 
4. Tax Haven variations. Investment in tax havens has no effect on the burden of proof in tax litigation. The government may estimate the taxpayer's liability based upon information available to it and that estimate is presumptively correct. The taxpayer has the burden to prove the government's determination of tax liability is incorrect. Both United States citizens and permanent United States residents are subject to tax on their worldwide incomes ${ }^{133}$ and the estates of citizens and permanent residents are subject to tax on all property the decedent owned worldwide. ${ }^{134}$ The taxpayer has a duty to report income ${ }^{135}$ from all sources on her income tax return and the fiduciary of the decedent's estate to report all property of the decedent on the estate tax return. ${ }^{136}$

Although not under a tax statute, each United States person must report her or its interests in foreign financial accounts to the IRS whenever the aggregate amount in those accounts exceeds US\$10,000. ${ }^{137}$ If a United States person fails to report or inaccurately reports the interest in the foreign account, the IRS may impose a basic penalty of US $\$ 10,000$ for each failure to report. ${ }^{138}$ The penalty increases to US\$100,000 or half the amount in the account if the violation is willful, so that aggregate penalties may exceed the total amount in the financial account. ${ }^{139}$ Procedurally, the IRS assesses and collects the penalty in the same manner as a tax or a tax penalty, but a general six year statute of limitations applies. ${ }^{140}$ Criminal prosecution for violation of the reporting requirement is also possible. ${ }^{141}$ Since the collection procedure mimics tax collection, the government has a burden to establish that it properly has assessed a penalty, and that showing requires production of the evidence that the United States person had the foreign account. In order to impose the increased penalties for willfulness, the government would bear the burden to prove the intent with clear and convincing evidence and, for criminal prosecution, beyond a reasonable doubt. Until recently, the IRS did not pursue reporting failures aggressively since it was exceedingly difficult to penetrate taxpayers' reporting or failure to report. ${ }^{142}$ A Treasury study discloses minimal reporting enforcement activity through $2001{ }^{143}$ Since 2006, the IRS has sought more actively to gain compliance with the foreign account reporting rules, including the sensational threatened prosecution of Swiss bank representatives and agreements with Switzerland and Liechtenstein on information sharing. ${ }^{144}$

\footnotetext{
${ }^{133}$ I.R.C. $\$ 61$.

${ }^{134}$ I.R.C. $\$ 2031$.

135 I.R.C. $\$ 6012$.

${ }^{136}$ I.R.C. $\$ 6018$.

137 31 CFR 103.24. The authority for the reporting requirement is 31 USC 5314 (recordkeeping and reporting requirement for financial accounts). See the FBAR (Report of Foreign Bank and Financial Account, originally Foreign Bank Account Report, hence FBAR), Form TD F 90.22.1 (available at http://www.irs.gov/pub/irspdf/f90221.pdf).

${ }^{138} 31$ USCS $\S 5321(\mathrm{a})(5)$.

${ }^{139} I d$.

14031 USCS $\S 5321(\mathrm{~d})$.

14131 USCS $§ 5322$.

${ }^{142}$ Income tax return forms, Form 1040, Schedule B for individuals (available at: http://www.irs.gov/pub/irspdf/f1040sb.pdf) includes questions on foreign accounts in lines 7 and 8 .

143 Secretary of the Treasury, A Report to Congress in Accordance with §361(B) of the

Uniting and Strengthening America by Providing Appropriate Tools Required to Intercept and Obstruct

Terrorism Act of 2001 (USA PATRIOT ACT) (available at:

http://www.ustreas.gov/press/releases/reports/fbar.pdf).

${ }^{144}$ See, generally, Part 6 of Henry Ordower, The Culture of Tax Avoidance, supra note 77.
}

Henry Ordower, Professor of Law

Saint Louis University School of Law

U.S. National Report: The Burden of Proof in Tax Matters 
In order to enhance collection of information concerning the foreign accounts of United States taxpayers, the United States has entered into a substantial number of tax treaties and information exchange agreements. ${ }^{145}$ In addition, under contractual agreements with the IRS, foreign financial institutions become qualified intermediaries. ${ }^{146}$ The IRS relies on the certification of participating foreign financial institutions that the beneficial owner of a United States source payment that passes through the qualified intermediary institution qualifies for treaty benefits. For non-treaty benefit qualifying recipients of United States source interest and dividends the qualified intermediary withholds in bulk and pays the withheld amounts over to United States. The qualified intermediary contracts did not require the foreign financial institutions to disclose customer identifying information to the IRS except in the case of United States taxpayers who were customers. Qualified intermediaries report United States source interest and dividends received for the benefit of United States taxpayers in the same manner as the institutions would report those payments if the institutions were United States institutions. ${ }^{147}$

Foreign institution participation in the United States qualified intermediary program is contingent upon information sharing and reporting. Recent developments with Switzerland and Liechtenstein disclose that some foreign participants encouraged their United States clients to create entities in low tax jurisdictions to receive the United States source payments and circumvent the strictures of the qualified intermediary rules. Thus while the qualified intermediary contracts offered benefits to both the IRS and the foreign financial institution, the system has not worked efficiently to prevent United States taxpayers from secreting income offshore through offshore entities. The qualified intermediaries do not inquire into those offshore entities' ownership and, accordingly, do not disclose to the IRS ownership by United States persons.

In order to correct many of the shortcomings of the qualified intermediary program, Congress recently enacted the Foreign Account Tax Compliance Act ("FATCA"). ${ }^{148}$ FATCA requires United States taxpayers to report their foreign accounts on their income tax returns and imposes significant new penalties on them if they fail to report. ${ }^{149}$ Additional penalties apply to failures to report foreign source income from those undisclosed foreign accounts. ${ }^{150}$ The statute of limitations for income from undisclosed foreign accounts is extended from three to six years. ${ }^{151}$ Foreign financial institutions under FATCA will be subject to thirty percent withholding on payments from United States sources, even if they are conduit payments to their account holders, unless they agree to perform necessary due

\footnotetext{
${ }^{145}$ For a report on treaties and information exchange agreements with Members of the EU, see Henry Ordower, United States of America Experience with and Administrative Practice concerning Mutual Assistance in Tax Affairs, prepared for the 2009 Congress of the European Association of Tax Law Professors (Santiago de Compostela, 2009), Chapter in Roman Seer, general reporter and ed., AdMINISTRATIVE PRACTICE CONCERNING Mutual ASSiSTANCE IN TAX AFFAIRS, (Amsterdam, forthcoming) (available as Saint Louis U. Legal Studies Research Paper No. 2010-16 at http://papers.ssrn.com/sol3/papers.cfm?abstract_id=1634027\#\#).

${ }^{146}$ Rev. Proc. 2000-12, 2000-1 C.B. 387.

${ }^{147}$ Under I.R.C. $\$ 6049$ (interest); I.R.C. $§ 6042$ (dividends). Reports are on a Form 1099.

${ }^{148}$ Hiring Incentives to Restore Employment (HIRE) Act of 2010, Pub. L. 111-147 (March 18,2010), included FATCA as its Title V.

${ }^{149}$ I.R.C. $\$ 6038 D$.

${ }^{150}$ I.R.C. $\$ 6661(\mathrm{~b})(7)(20$ percent for substantial understatements and 40 percent for gross understatements). ${ }^{151}$ I.R.C. $\$ 6501(\mathrm{e})(1)(\mathrm{A})(\mathrm{ii})$.
}

Henry Ordower, Professor of Law

Saint Louis University School of Law

U.S. National Report: The Burden of Proof in Tax Matters 
diligence to identify and then disclose to the IRS any underlying direct or indirect ownership of accounts by United States taxpayers. ${ }^{152}$ FATCA does not alter any burden of proof rules.

5. Level of Burden of Proof. See discussion in Part I above. The burden of proof in civil tax matters is the preponderance of the evidence. In civil penalty matters where the taxpayer's knowledge or intention is critical to the imposition of the penalty, the standard is clear and convincing evidence. In criminal tax matters, the standard is proof beyond a reasonable doubt. All standards emerge from the judicial decisions and practice with the criminal standard being common to criminal law in general.

The United States has extensive recordkeeping, disclosure and third party reporting requirements. Those requirements impact the taxpayer's ability to carry her burden of proof by producing credible evidence in support of her position. Taxpayers and third parties who have a return filing obligation must maintain the records that the treasury regulations require. ${ }^{153}$ For the taxpayer, failure to maintain the necessary records precludes the taxpayer from shifting the burden of proof to the government. ${ }^{154}$

Recordkeeping requirements are not uniform throughout the United States tax law. A leading case ${ }^{155}$ addressing entertainment expenses required the government to make a reasonable estimate of minimal expenditures in light of the taxpayer's trade or business activity and allow a deduction as an ordinary and necessary business expense for that estimated amount even if the taxpayer maintained no records. ${ }^{156}$ Taxpayers claiming business expenses as employees generally must maintain "such records as will be sufficient to enable the Commissioner to correctly determine income tax liability." 157 On the other hand, there are specific and detailed substantiation requirements for charitable contributions that exceed US\$ 250 to a single donee organization ${ }^{158}$ and even appraisal requirements for charitable contributions of property other than money having a value in excess of US\$5000. ${ }^{159}$ As with most recordkeeping requirements, including the required acknowledgement from a charitable donee, the taxpayers has to produce the records to substantiate her return at the IRS's request but need not submit the records with her return. Appraisals for charitable contributions are an exception. The taxpayer claiming the deduction must submit the appraisal with the tax return.

In addition to the taxpayer's recordkeeping requirements, many third parties must report taxpayer information to the IRS. Information reporting applies to persons making or facilitating payments of interest, ${ }^{160}$ dividends, ${ }^{161}$ amounts of US\$600 or more to one person

\footnotetext{
152 I.R.C. $\$ 1471$.

${ }^{153}$ I.R.C. $\$ 6001$.

${ }^{154}$ I.R.C. $\$ 7491(a)(2)(A)$ (taxpayer must comply with substantiation requirement of the Code and Treasury

Regulations in order to make use of I.R.C. $\S 7491(a)(1)$ to shift the burden of proof to the government).

${ }^{155}$ Cohan v. Commissioner, 39 F.2d 540 (2d Cir. 1930).

${ }^{156}$ I.R.C. $\$ 162$ (a) (deduction for ordinary and necessary business expenses) as currently limited by I.R.C. $\$ 274$

(limitations on entertainment expenses).

${ }^{157}$ Treas. reg. $\S 1.162-17(\mathrm{~d})(2)$.

${ }^{158}$ I.R.C. $\$ 170(\mathrm{f})(8)$.

${ }^{159}$ I.R.C. $\$ 170(\mathrm{f})(11)$.

${ }^{160}$ IRC $\$ 6049$ (requiring information reporting on payments of interest aggregating $\$ 10$ or more).

${ }^{161}$ IRC $\$ 6042$ (requiring information reporting on dividend distributions aggregating $\$ 10$ or more).
}

Henry Ordower, Professor of Law

Saint Louis University School of Law

U.S. National Report: The Burden of Proof in Tax Matters 
from their trades or businesses, ${ }^{162}$ and many other types of business payments. Failure to report renders the obligated reporting party liable for a penalty unless the reporter corrects the failure to report within reasonable periods specified in the statute. ${ }^{163}$ The IRS collects and matches electronically much of the information that third parties report with the recipients' tax returns. Existence of a third party report is credible evidence that the taxpayer received the income, so that a taxpayer seeking to shift the burden of proof to the IRS would have to refute that report with credible evidence that the reporting party made an error. If the taxpayer received the third party report but did not include the amount in her income, for penalty purposes, the taxpayer would seem to be failing to report income willfully. Increasingly the IRS relies on information reporting and disclosure requirements to gather taxpayer information and compare it with what the taxpayer voluntary reports.

While many reporting rules provide routine factual information to the IRS, other rules target transactions that the IRS has identified as potential tax avoidance opportunities. For example, a group of Code provisions requires information reporting of transactions' characteristics and taxpayer identifying information on participants in specific investment structures, especially tax shelters. ${ }^{164}$ Significant penalties apply to taxpayers who fail to report their participation in the transactions on their returns. ${ }^{165}$

Recently, the IRS, through its rule-making authority imposed a requirement that certain corporate taxpayers disclose their uncertain tax positions. ${ }^{166}$ Historically, taxpayers did not have to disclose aggressive and risky tax positions where the outcome of litigation on the matter would be hard to predict. Often the taxpayer embedded those positions in its return making the position difficult - sometimes virtually impossible - for the IRS to identify. While disclosure might relieve taxpayers of exposure to certain penalties, ${ }^{167}$ corporate taxpayers tended to rely on non-disclosure followed by defense of the position if the IRS did identify and question it.

In announcing the new disclosure schedule, ${ }^{168}$ the IRS emphasized that public reporting companies must disclose and reserve for uncertain tax positions in their financial statements. ${ }^{169}$ Since the corporations have to assemble the tax reporting information for their auditors, the additional burden of disclosing the information to the IRS would not be

\footnotetext{
${ }^{162}$ IRC $\$ 6041$ (requiring information reporting on payments of $\$ 600$ or more in one's trade or business).

${ }^{163}$ I.R.C. $\$ 6721$, for example.

${ }^{164}$ I.R.C. $\$ 6111$ (requiring material advisers on reportable transactions to report the transactions). I.R.C. $\$ 6112$ (material advisors must keep a list of investors).

${ }^{165}$ I.R.C. $\$ 6707 \mathrm{~A}$ (penalties for failing to report reportable transaction participation and higher penalties for failure to report listed transaction participation). Under I.R.C. $\S 6707 \mathrm{~A}(\mathrm{c})$, a reportable transaction is one the IRS designates as having potential to have a tax avoidance purpose, and a listed transaction is one similar to a transaction the IRS identifies as having a tax avoidance purpose.

${ }^{166}$ Schedule UTP (available at http://www.irs.gov/pub/irs-pdf/f1120utp.pdf) promulgated pursuant to prop. Treas. reg. §1.6012-2(a)(4), 75 Fed. Reg. 54802 (September 9, 2010). See Announcement 2010-75 Uncertain Tax Positions, 2010-41 I.R.B. 428, (September 24, 2010) (explaining modifications to the original proposal based upon industry comments).

${ }^{167}$ I.R.C. $\$ 6661$ (accuracy related penalties).

${ }^{168}$ Announcement 2010-9, 2010-7 IRB 408; see also Announcement 2010-17, 2010-13 I.R.B. 515 and Announcement 2010-30, I.R.B. 2010-19.

${ }^{169}$ Financial Accounting Standards Board Interpretation 48, Accounting for Uncertainty in Income Taxes: An Interpretation of FASB Statement 109 ("Fin 48") (2006) (requiring reporting companies to disclose and reserve for the liability from uncertain tax positions unless they were more likely than not to be sustained in litigation).
}

Henry Ordower, Professor of Law

Saint Louis University School of Law

U.S. National Report: The Burden of Proof in Tax Matters 
substantial. The required disclosures do not include the taxpayer's risk assessment or the specific amounts reserved. ${ }^{170}$ Required disclosures do include:

1. The Code sections potentially implicated by the position;

2. A description of the taxable year or years to which the position relates;

3. A statement that the position involves an item of income, gain, loss, deduction, or credit against tax;

4. A statement that the position involves a permanent inclusion or exclusion of any item, the timing of that item, or both;

5. A statement whether the position involves a determination of the value of any property or right; and

6. A statement whether the position involves a computation of basis. ${ }^{171}$

The IRS continues to clarify requirements for the disclosure schedule. Recently it issued a series of questions and answers to assist taxpayers in ascertaining whether they must report a position or not. ${ }^{172}$ The questions and answers clarify that the disclosure schedule depends upon the existence of required reserves in the financial statements for uncertain tax positions. ${ }^{173}$ In addition, one of the questions clarifies that the taxpayer need not disclose its position for which it reserves based upon a pre-2010 event that gave rise to a net operating loss carryover. ${ }^{174}$

While information reporting and disclosure requirements do not alter the general rules for the allocation of the burden of proof in tax matters, they do render the allocation of the burden of proof substantially irrelevant in many instances. Burden of proof concerns itself with issues of fact, not application of the law. Often accurate and detailed information reporting and disclosure eliminates factual uncertainty from tax controversies. Only issues of interpretation and application of the law to the facts remain as the outcome determinants in tax disputes. Interpretation and application are primarily legal issues within the expertise of professional judges based upon their own independent analysis of the law in light of available precedents and official interpretations in treasury regulations. Appeals officers seek to anticipate how the judges will apply the law to the facts in making their "hazards of litigation" case evaluations. ${ }^{175}$

6.- 9. Evidentiary Requirements. No limitations or differences in evidentiary requirements apply to differing procedural postures in tax matters. As long as the evidence that either the government or the taxpayer presents is probative, credible, and admissible, the court or other trier of fact will determine its relative weight in rendering a decision. Appeals

${ }^{170}$ In Announcement 2010-76, 2010-2 C.B. 432, Requests for Documents Provided to Independent Auditors, Policy of Restraint and Uncertain Tax Positions, the IRS stated that it would not assert waiver attorney-client privilege with respect to privileged documents that the taxpayer provided to its auditors to enable the auditors to comply with reporting requirements for its tax positions.

${ }_{171}$ Announcement 2010-9, supra note 168.

${ }^{172}$ Frequently Asked Questions on Schedule UTP (available at http://www.irs.gov/businesses/article/0,,id=237538,00.html).

${ }^{173}$ Fin 48, supra note 169.

${ }^{174}$ I.R.C. $\$ 172$ (a taxpayer having a loss in its business that exceeds its income may use the loss in both earlier and later tax years from the year in which the taxpayer incurred the loss).

${ }^{175}$ See discussion of the Appeals' function, supra in Part I.A. of this report.

Henry Ordower, Professor of Law

Saint Louis University School of Law

U.S. National Report: The Burden of Proof in Tax Matters 
officers also evaluate the relative weight of the taxpayer's and the government's evidence in analyzing the "hazards of litigation."

On evidentiary matters, the Tax Court generally follows the Federal Rules of Evidence $^{176}$ but departs from them in some respects and admits some evidence that might be excluded under those Rules. The Court of Federal Claims and the District Courts follow the Federal Rules of Evidence. Evidentiary standards and requirements are independent of the type of tax and the taxpayer has no greater evidentiary burden in instances in which the government has difficulty accessing the third party records relating to the taxpayer. ${ }^{177}$ United States law requires taxpayers to report and disclose matters that are relevant to the determination of their tax liability and imposes penalties to enforce and encourage compliance with the disclosure and reporting requirements. ${ }^{178}$

10. General Anti-Abuse Provisions. Many commentators view the new economic substance provision of the Code to be a general anti-abuse rule. ${ }^{179}$ Unlike the Swedish, German, and Canadian anti-abuse rules for example, the economic substance provision is primarily definitional. It lacks an internal operating rule. The statute instead clarifies that a transaction lacks economic substance unless:

"(A) the transaction changes in a meaningful way (apart from Federal income tax effects) the taxpayer's economic position, and

(B) the taxpayer has a substantial purpose (apart from Federal income tax effects) for entering into such transaction." 180

The definition combines the elements of the economic substance doctrine ${ }^{181}$ and the business purpose test ${ }^{182}$ that the IRS applied before the statute's enactment to challenge tax planning structures. If the doctrine applies, the IRS may use the doctrine to recast a transaction according to its economic substance and disallow the intended tax benefits of the transaction, as the IRS would have done under pre-enactment application of the doctrine.

In addition to and possibly more significant than the disallowance of the intended tax benefits of the transactions that lack economic substance is the imposition of a strict liability penalty of twenty percent of the amount of additional tax imposed by virtue of the disallowed benefits. ${ }^{183}$ The penalty doubles to forty percent if the taxpayer does not disclose the

\footnotetext{
${ }^{176} 28$ USC app Rule 101 et seq., PL 93-595 (January 2, 1975, as amended).

${ }^{177}$ Compare the Report on the FBAR, supra note 143, disclosing the difficulty for the government of gathering evidence of taxpayers' non-compliance with the reporting requirements.

${ }^{178}$ For example, I.R.C. $\$ 6662(d)(2)(B)$ reduces the taxpayer's penalty for substantial understatement of income tax if the taxpayer adequately discloses the position or transaction causing the understatement and had a reasonable, albeit incorrect, basis for the position, unless the position is a tax shelter defined under I.R.C. $\S 6662(\mathrm{~d})(2)(\mathrm{C})$ as an investment having the avoidance or evasion of tax as a significant purpose. See, similarly, I.R.C. $\$ 6664(d)(2)$ for a more general reasonable cause exception for disclosed transactions.

${ }^{179}$ I.R.C. $\$ 7701(\mathrm{o})$, supra note 78 and authorities cited there.

${ }^{180}$ I.R.C. $\$ 7701(0)(1)$.

${ }^{181}$ See note 187 infra (economic substance).

${ }_{182}^{182}$ See note 185 infra (business purpose).

${ }^{183}$ I.R.C. $\$ 6662(\mathrm{~b})(6)$.
}

Henry Ordower, Professor of Law

Saint Louis University School of Law

U.S. National Report: The Burden of Proof in Tax Matters 
transaction and its facts when the taxpayer files her return. ${ }^{184}$ Since it is a strict liability penalty that requires no showing of the taxpayer's state of mind, the taxpayer carries the burden of proof to refute its assessment by establishing that the transaction had economic substance, or, in order to reduce the penalty to twenty percent, that the taxpayer indeed disclosed the transaction. The government need not produce clear and convincing evidence as it would have to do if the taxpayer's willfulness were at issue.

11. Anti-Abuse Supplementary Approaches. In the United States, courts and the Department of the Treasury in regulations have applied interpretive glosses like the sham transaction, ${ }^{185}$ business purpose, ${ }^{186}$ economic substance ${ }^{187}$ and substance over form ${ }^{188}$ doctrines, and even a general anti-abuse rule for partnerships ${ }^{189}$ to prevent tax reducing schemes. These doctrines and rules have no effect on the distribution of the burden of proof. Because Congress so recently enacted what may be a general anti-abuse rule, it is too early to know whether or not the IRS will rely exclusively on the statutory rule or continue to use a variety of anti-abuse doctrines. Moreover, the courts have not spoken as yet to the question of whether or not the new statutory rule occupies the anti-abuse field and supplants all other doctrines.

12. Special Anti-Abuse provisions. The partnership anti-abuse rule ${ }^{190}$ would enable the IRS to recast a partnership structure or its transactions to reflect the purposes of the partnership tax rules. It does not alter the burden of proof. The IRS has not sought to rely on the partnership anti-abuse rule in any meaningful way and it has played a minimal role in litigation.

Transfer pricing rules ${ }^{191}$ enable the IRS to reallocate income and deduction among related taxpayers so that those rules resemble anti-abuse rules. Similarly, the Code contains a broad array of provisions that recharacterize transactions, reallocate income and deduction between or among taxpayers, and discourage certain tax practices by eliminating or diminishing their intended tax benefits. Some examples of provisions which disallow tax benefits automatically or with the intervention of the IRS include: (i) deductions from acquisitions made to avoid tax; ${ }^{192}$ (ii) sales of property to related persons at a loss; ${ }^{193}$ (iii) sales of corporate stock at a loss followed or preceded by reinvestment in stock of the same corporation (so-called "wash sales"); ${ }^{194}$ and (iv) gifts within three years of death avoiding the

\footnotetext{
${ }^{184}$ I.R.C. $§ 6662(i)$. economic substance). for the reorganization. Treas. reg. $\$ 1.368-1(\mathrm{c})$. income on the distribution).

${ }^{189}$ Treas. reg. $\$ 1.701-2$.

${ }^{190} \mathrm{Id}$.

${ }^{191}$ I.R.C. $\$ 482$ and regulations under the statute.

${ }^{192}$ I.R.C. $\$ 269$

${ }^{193}$ I.R.C. $\$ 267$

${ }^{194}$ I.R.C. $\$ 1091$.
}

${ }^{185}$ Knetsch v. U.S., 364 U.S. 361 (1960) (holding that interest paid on insurance borrowing was a sham lacking

${ }^{186}$ The regulations governing tax deferred reorganization require the taxpayer to demonstrate a business purpose

${ }^{187}$ Estate of Franklin v. Commissioner, 544 F.2d 1045 (9th Cir. 1976) (holding the taxpayer had no economic interest in property where the debt encumbering the property greatly exceeded the property's value).

${ }^{188}$ Helvering v. Gregory, 69 F.2d 809, 810 (2d Cir. 1934), aff'd. as Gregory v. Helvering, 293 US 465 (1935) (steps collapsed when taxpayer caused corporation to engage in a divisive reorganization under the statute, spinning off a corporation that held only shares of a third corporation; taxpayer liquidated the spun off corporation in order to sell the third corporation shares and have capital gain, rather than ordinary dividend

Henry Ordower, Professor of Law

Saint Louis University School of Law

U.S. National Report: The Burden of Proof in Tax Matters 
estate tax. ${ }^{195}$ None of those anti-abuse type rules affect the allocation or degree of the burden of proof.

13. Competent Authority. The examination function within the IRS determines initially whether the taxpayer has met her burden of proof. If the examiner believes that the taxpayer has established her tax liability adequately and accurately, the examiner may close the file without adjustment. Similarly, in selecting an acceptable compromise of the taxpayer's liability under its "hazards of litigation" analysis, Appeals determines whether and to what degree the taxpayer has met her burden of proof. Ultimately, the court which the taxpayer chooses for litigation determines whether the parties have met their burdens of proof or production. The burden of proof is the same at administrative and judicial determination levels but, as a practical matter, and not as a matter of law, Appeals may impose a lower burden of proof on the taxpayer in order to bring about compromise than the examiner might. In the interest of collecting tax revenue efficiently and quickly, the examiner might require less evidence and impose a lower burden than a court would.

14. Judicial Review. See previous question response. The burden of proof is the same at all tax review levels: examination, Appeals or court proceedings. Courts review all issues that the taxpayer raises in her petition to Tax Court or complaint in District Court or the Court of Federal Claims. In addition, appellate courts defer to the decisions of the trial court on findings of fact unless the trial court's finding was clearly erroneous. ${ }^{196}$ Burden of proof goes primarily to facts not law.

15. Case Law. See the discussion of precedent in Part III.A. above. Case law ultimately controls the interpretation and application of statutes in the United States. Courts follow their own earlier decisions as well as decisions of other courts. Occasionally a court will find that the government abused its discretion in its application of the tax laws and somewhat more frequently in its collection procedures.

Congress expressed somewhat disingenuous concern with "excesses" in the administrative activities of the IRS and sought to limit them with a number of statutes including especially the Internal Revenue Service Restructuring and Reform Act of $1998 .{ }^{197}$ That statute gave taxpayers an opportunity to report unreasonable and harassing activities of IRS employees. ${ }^{198}$ If, following an administrative hearing and subject to court review, the IRS determined that an employee violated the act, the employee could lose his job. This taxpayer protective legislation altered the distribution of burden of proof by permitting the taxpayer to shift the burden to the government by producing credible evidence in support of her position. ${ }^{199}$

The courts in the United States have not expressed concern or discomfort with uncertainty in the tax law. In applying anti-avoidance doctrines to recent tax sheltering

\footnotetext{
${ }^{195}$ I.R.C. $\$ 2035$ (the gift tax being tax exclusive and the estate tax inclusive, this provision historically was a rebuttable presumption related to the decedent's possible contemplation of death).

${ }^{196}$ Duberstein v. Commissioner, 363 US 278 (1960) supra note 24.

${ }^{197}$ The IRRA, supra note 17, represents the nadir of respect for the IRS in the United States. The author of this report surmises and has commented elsewhere, Ordower, Culture of Tax Avoidance, supra note 77, that some members of Congress chose to punish the IRS in order to gain political support.

${ }^{198}$ Id. Section 1203 of IRRA listed ten acts of an IRS employee that would result in permanent separation from employment with the IRS.

${ }^{199}$ I.R.C. $\$ 7491$ (a) and discussion supra in Part I.B..
}

Henry Ordower, Professor of Law

Saint Louis University School of Law

U.S. National Report: The Burden of Proof in Tax Matters 
activity, the courts have focused their attention on whether or not the taxpayer's transaction meets the definitional criteria that underlie the taxpayer's chosen tax characterization. If the transaction does not, the IRS may recharacterize the transaction less favorably for tax purposes. ${ }^{200}$ Arguments that anti-avoidance doctrines prevent taxpayers from achieving certainty as to the tax characterizations of their transactions have not gained traction in the courts although the issue of uncertainty has been recurrent in the objections of members of the community of tax professionals to the codified economic substance doctrine. ${ }^{201}$

Similarly, unlike the Constitutional Court in Germany that takes a strong position on horizontal, but not vertical, equity in German taxation, ${ }^{202}$ the United States Supreme Court has applied its least stringent review methodology to arguments of tax inequality. The Court required no more than a rational basis for the inequality to find the statute to be constitutionally permissible. ${ }^{203}$ While the Court required a county to assess property for tax purposes substantially uniformly, ${ }^{204}$ it upheld the state constitutional limitation on assessment that discriminated against owners of recently purchased property because it rationally protected long term owners from rapid property tax increases. ${ }^{205}$ Earlier the Court permitted sex based discrimination because the state had a rational basis in recognizing the lower earning power of women for the inequality that gave widows a property tax exemption but not widowers. ${ }^{206}$ The Supreme Court generally has been intolerant of state tax structures that discriminate in favor of state residents ${ }^{207}$ but not when the discrimination favors out of state businesses in order to encourage them to invest in the state. ${ }^{208}$

16. EC law and the reversal of the burden of proof. The United States remains independent of any EC jurisprudence so the Leur-Bloem decision has had no effect on United States tax law.

The taxpayer in the United States has the burden of proof in tax controversies. In addition, many tax statutes originate in presumptions that certain types of transactions are likely to have tax avoidance as one of their purposes. Most of those statutes simply alter the tax characterization of the transaction automatically without inquiring into underlying facts that might permit the taxpayer to rebut the presumption. ${ }^{209}$ Other provisions permit the taxpayer to establish to the satisfaction of the IRS that tax avoidance was not one of the

\footnotetext{
${ }^{200}$ For example, BB\&T Corp. v. United States, 523 F.3d 461 (4th Cir. 2008) (recharacterizing a lease in, lease out transaction as a financing transaction rather than a true lease and sublease as the taxpayer reported the transaction).

${ }^{201}$ See response to question 10 supra.

${ }^{202}$ BVerfGE 107, 27 at 46 (December 4, 2002) (chain away from home work assignments treated more favorably for tax purposes than a permanent away from home work location held unconstitutional).

${ }^{203}$ Most of the Court's pronouncements have addressed state rather than federal taxes.

${ }^{204}$ Allegheny Pittsburgh Coal Co. v. County Commission of Webster County, West Virginia, 488 US 336, 345 (1989).

${ }^{205}$ Nordlinger v. Hahn, 505 US 1, 17-18 (1992).

${ }^{206}$ Kahn v. Shevin, 416 US 351 (1974).

${ }^{207}$ Metro. Life Ins. Co. v. Ward, 470 U.S. 869 (1985) (tax preference for in state insurers).

${ }^{208}$ Allied Stores of Ohio v. Bowers, 358 U.S. 522 (U.S. 1959) (personal property tax exemption for out of state businesses storing goods in Ohio).

${ }^{209}$ For example, I.R.C. $\$ 267$ denies loss deductions to taxpayers who sell property to related taxpayers; I.R.C. $\S 1091$ disallows losses on wash sales of corporate shares; I.R.C. $\$ 246$ denies the dividends received deduction to corporations investing and disinvesting in another corporation during a 45 day period before and after an exdividend date.
}

Henry Ordower, Professor of Law

Saint Louis University School of Law

U.S. National Report: The Burden of Proof in Tax Matters 
principal purposes for the transaction. ${ }^{210}$ Where there is a statutory presumption that a transaction has a tax avoidance purpose, the taxpayer must demonstrate with clear and convincing evidence, rather than a simple preponderance of the evidence, that a non-tax avoidance purpose is the principal purpose of the transaction.

Despite the taxpayer having the burden of proof, the IRS has not enjoyed overwhelming success in the courts in arguing that the taxpayer engaged in a transaction for tax avoidance purposes. The threshold for the taxpayer to carry her burden of proof in economic substance cases historically has been low. ${ }^{211}$ In most jurisdictions, the taxpayer had only to demonstrate that she either had a non-tax business purpose (profit motive) for the transaction or some reasonable possibility of deriving a profit from the transaction. ${ }^{212}$ A few jurisdictions required that the taxpayer establish both a non-tax business purpose for the transaction and a reasonable likelihood of deriving a profit from the transaction. ${ }^{213}$ Codification of the economic substance doctrine in 2010 requires both a non-tax business purpose and probability of non-tax profit ${ }^{214}$ and may make it more difficult for taxpayers establish economic substance.

17. Reversal of burden of proof and time limits. Tax deferred reorganizations in the United States ${ }^{215}$ require both continuity of proprietary interests ${ }^{216}$ and continuity of business enterprise. ${ }^{217}$ Continuity of business enterprise requires that the acquiring corporation either continue the target corporation's historic business or use a significant portion of the targets historic business assets in a business. ${ }^{218}$ Continuing to use assets relates to operating assets rather than investment assets. The requirement is not onerous.

As to continuity of proprietary interest, each reorganization structure which corporations and their shareholders may utilize to combine separate corporate enterprises without recognizing gain or loss currently has its own requirements for continuity of proprietary interests. Stock for stock acquisitions require that the acquiring corporation utilize only its own voting stock to purchase the shares of the target corporation, ${ }^{219}$ while statutory mergers permit the acquiring corporation to use both any mix of its own shares and as much as fifty percent or more non-qualified property such as cash to consummate the reorganization. $^{220}$ The permissible non-qualified consideration ceiling for statutory mergers

\footnotetext{
${ }^{210}$ I.R.C. $\$ 306(b)(4)$ (dividends payable in preferred stock followed by sale or redemption of the preferred).

${ }^{211}$ Gregory v. Helvering, 293 U.S. 465 (1935) (Judge Hand observing that taxpayers may arrange their affairs to minimize their taxes but holding the transaction in question lacked the necessary business purpose for a corporate reorganization).

${ }^{212}$ Frank Lyon Co. v. United States, 435 U.S. 561 (1978) (sale-leaseback transaction having minimal opportunity for profit held to have a non-tax business purpose sufficient to cause the transaction to be respected for tax purposes).

${ }^{213}$ ACM Pshp. v. Commissioner, 157 F.3d 231 (3d Cir. 1998), cert. denied, 526 U.S. 1017 (1999) (contingent installment note structured transaction to generate capital loss lacked economic substance).

${ }^{214}$ I.R.C. $\$ 7701(0)$.

${ }^{215}$ I.R.C. $\$ 368$ (a) defines the various types of acquisitive reorganizations. I.R.C. $\$ 355$ describes the statutory requirements for divisive reorganizations.

${ }^{216}$ Treas. reg. $\S 1.368-1(\mathrm{e})$.

${ }^{217}$ Treas. reg. $\$ 1.368-1(\mathrm{~d})$.

${ }^{218} I d$.

${ }^{219}$ I.R.C. $\$ 368(a)(1)(B)$ (solely for voting stock requirement in stock for stock reorganizations).

${ }^{220}$ I.R.C. $\$ 368(a)(1)(A)$ (statutory merger with no express requirement on consideration).
} 
emerged from judicial decisions, ${ }^{221}$ but the treasury regulations now confirm that at least fifty percent of the consideration may be non-qualified consideration. ${ }^{222}$ If the target's shareholders shares have appreciated in value, the shareholders recognize gain to the extent of (i) consideration other than stock of the acquiring corporation they receive or (ii) the amount of appreciation if it is less than the amount of non-qualified consideration. ${ }^{223}$ Continuity of proprietary interest by the target corporation's historical shareholders following the reorganization is not critical. Target shareholders may dispose of the acquiring corporation's shares without affect the reorganization status. ${ }^{224}$ Selling shareholders will end their tax deferral and recognize gain or loss on the sale of the shares. EU tax law does not affect taxation in the United States.

18. Reversal of burden of proof and transactions with non-domestic entities. United States tax law includes several provisions that prevent the expatriation of property in transactions lending themselves to possible tax abuse. The Code forces the recognition of gain on the transfer of property to a foreign corporation by treating the foreign corporation as if it were not a corporation where the transfer of the same property to a United States corporation would enjoy deferral of gain recognition. ${ }^{225}$ In order to facilitate necessary business adjustments, however, this gain recognition rule does not apply to the transfer a foreign branch's active business assets from a United States corporation to a foreign corporation. ${ }^{226}$ Nevertheless, if the United States corporation deducted losses of the foreign branch greater in amount than the income of the foreign branch it included, the United States corporation will recognize gain to the extent of that excess. A more stringent gain and income inclusion rule applies to so-called corporate inversion transactions in which a United States operating corporation shifts its location of incorporation offshore. ${ }^{27}$ Where the former shareholders of the United States corporation continue to own at least sixty percent of the foreign corporation, then, for the next ten years, much of the corporate income will continue to be taxable in the United States. ${ }^{228}$ If former shareholders of the United States corporation continue to own at least eighty percent of the foreign corporation, the foreign corporation will be a United States corporation for tax purposes and subject to tax on its worldwide income in the United States. ${ }^{229}$ This anti-inversion statute also applies to United States partnerships and limited liability companies that are tax transparent entities. ${ }^{230}$ Also the general expatriation statute forces individuals who relinquish their United States citizenship (or residence in the case of long term resident aliens) to recognize gain as if they sold all their assets at the time

\footnotetext{
${ }^{221}$ For example, John A. Nelson Co. v. Helvering, 296 US 374 (1935) (held to be a tax deferred reorganization although more than half the consideration was cash and the remainder non-voting preferred stock).

222 Treas. reg. $\$ 1.368-1(\mathrm{e})(8)$, Ex. 1.

${ }^{223}$ I.R.C. $\$ 356$ (recognition of boot as income or gain in a reorganization).

${ }^{224}$ Treas. reg. $\$ 1.368-1(\mathrm{e})(8)$, Ex. 1.

${ }^{225}$ I.R.C. $\$ 367(\mathrm{a})(1)$.

${ }^{226}$ I.R.C. $\$ 367(\mathrm{a})(3)$.

${ }^{227}$ I.R.C. $\$ 7874$ (expatriated entities).

${ }^{228}$ I.R.C. $\$ 7874(\mathrm{~d})(2)$.

${ }^{229}$ I.R.C. $\$ 7874(\mathrm{~b})$.

${ }^{230}$ I.R.C. $\$ 7874(a)(2)$ (defining expatriated entity to include a partnership). The partnership tax rules under subchapter $\mathrm{K}$ of the Code apply to both partnerships and limited liability companies. Those rules provide for tax transparency so that the owners are subject to tax on the entity's income rather than the entity itself as in the case of a corporation.
}

Henry Ordower, Professor of Law

Saint Louis University School of Law

U.S. National Report: The Burden of Proof in Tax Matters 
of expatriation. ${ }^{231}$ In all instances, the taxpayer bears the burden to prove inapplicability of the statute.

In addition to specific rules governing transfers to foreign persons, the more general provisions that automatically disallow losses in the case of sales to related persons ${ }^{232}$ or permit the IRS to reallocate income between or among related persons continue to apply. ${ }^{233}$

19. Donations to foreign charitable institutions and the burden of proof. United States tax law does not permit a charitable contribution deduction for gifts to foreign charitable institutions. ${ }^{234}$ Most foreign charities accommodate themselves to this limitation by forming a United States feeder organization that is a qualified recipient of charitable contributions. The United States based organization applies for qualification as a charitable organization. ${ }^{235}$ In order to qualify, the organization provides documentation that insures that the organization has a proper charitable purpose and no part of its income or assets inures to the benefit of any non-charitable beneficiary. ${ }^{236}$ And the organization may not use any material part of its assets for lobbying or political intervention on behalf of a candidate. ${ }^{237}$ The IRS rules on the charitable status of an organization, and, the case of a denial of exemption, the organization may petition the Tax Court, the Court of Federal Claims or the district court for a declaratory judgment of its exempt status. ${ }^{238}$ The organization has the burden to prove its entitlement to exempt status. That the organization uses its assets to support charitable activities outside the United States does not affect the organization's qualification.

20. The burden of proof and proportionality. Statutory and decisional law in the United States is not in line with the proportionality principle of the SGI-case. If the IRS determines that a payment is not reasonable, it may determine a tax deficiency under its normal procedures. Numerous provisions of the Code impose limitations based on a concept of reasonableness. For example, compensation is deductible only if it is reasonable. ${ }^{239}$ Similarly, the IRS has broad authority to reallocate payments between or among related entities. $^{240}$ The taxpayer has the burden of proof but may shift the burden of proof to the IRS by producing credible evidence that the payment is reasonable. ${ }^{241}$ Time limits for production of evidence remain subject to the standard statute of limitations. ${ }^{242}$

\section{Transfer Pricing Aspects}

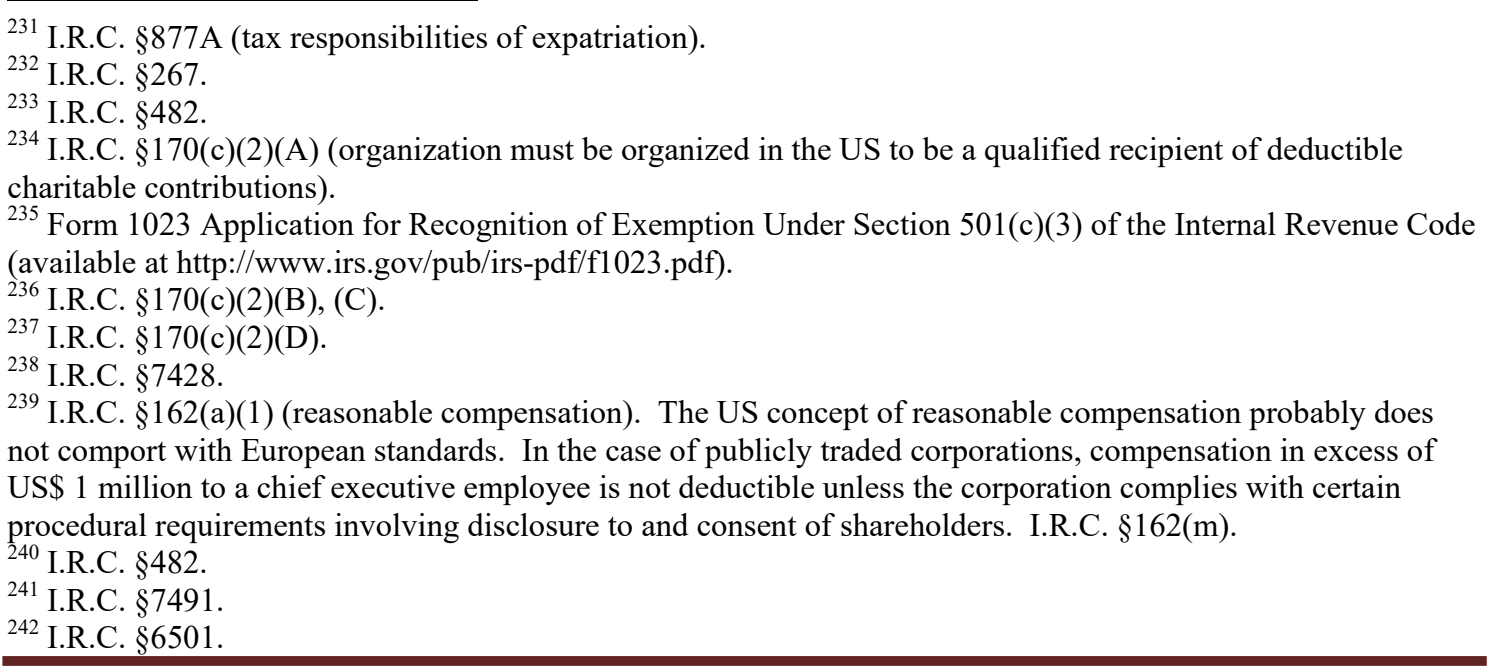

Henry Ordower, Professor of Law

Saint Louis University School of Law

U.S. National Report: The Burden of Proof in Tax Matters 
21. The burden of proof between tax authorities and taxpayers. As with other tax matters in the United States, the taxpayer initially bears the burden of proof that its transfer prices are at arm's length. ${ }^{243}$ The taxpayer may shift the burden of proof to the IRS by producing credible evidence that the transfer price is an arms' length price. ${ }^{244}$

\section{Set of documents.}

A. Documentation, generally. The operative transfer pricing statute does not require specific documentation for transfer prices in transactions between related parties. The statute is general and reads in part:

... the Secretary may distribute, apportion, or allocate gross income, deductions, credits, or allowances between or among such organizations, trades, or businesses, if he determines that such distribution, apportionment, or allocation is necessary in order to prevent evasion of taxes or clearly to reflect the income of any of such organizations, trades, or businesses. ${ }^{245}$

Treasury regulations interpreting that statute suggest the type of documentation and data that a taxpayer might maintain to support its transfer pricing ${ }^{246}$ but, except for shared services, ${ }^{247}$ do not require the taxpayer to maintain specific documentation. ${ }^{248}$

Contemporaneous documentation supporting the transfer price, however, is critical to avoiding penalties when the IRS reallocates receipts or payments between or among related taxpayers. ${ }^{249}$ If the IRS correctly determines (i) that the ratio between the transfer price reported and the correct price is two or more to one or (ii) the adjustment that the IRS makes to the taxpayer's transfer price "exceeds the lesser of $\$ 5,000,000$ or 10 percent of the taxpayer's gross receipts," then the taxpayer has made a substantial valuation misstatement. ${ }^{250}$ If the ration in (i) above is 4 to 1 or greater, the taxpayer has made a gross valuation misstatement. In determining whether or not the transfer price adjustment meets the (i) two to one test or (ii) the $\$ 5$ million or 10 percent test, the taxpayer may exclude that portion of the transfer price adjustment for which the taxpayer has contemporaneous documentation supporting the reasonableness of its transfer price method. In order to exclude some portion of the adjustment, the taxpayer must provide that contemporaneous documentation within thirty days of the IRS's request for the documentation. According to the IRS's compliance directive, the request for documentation under the regulation is a routine part of the transfer pricing audit process. ${ }^{251}$

The tax liability attributable to the substantial valuation misstatement, including the portion that the taxpayer was able to exclude in determining whether or

${ }^{243}$ I.R.C. $\$ 482$. Treas. reg. $\$ 1.482-1(b)$.

244 I.R.C. $\$ 7491$.

${ }^{245}$ I.R.C. $\$ 482$.

${ }^{246}$ Treas. reg. §1.482-1 through-9T.

${ }^{247}$ Treas. reg. §1.482(j)(2) (express documentation requirements for cost sharing arrangements).

248 Treas. reg. $\$ 1.482-1(\mathrm{~d})$ (comparability to uncontrolled transactions).

${ }^{249}$ I.R.C. $\$ 6662(\mathrm{a}),(\mathrm{e})(3)$. See discussion of documentation infra in text accompanying note 262.

${ }^{250}$ I.R.C. $\$ 6662(\mathrm{e})$.

${ }^{251}$ LMSB Commissioner, Directive Transfer Pricing Compliance Process (January 22, 2003) (available at: http://www.irs.gov/businesses/international/article/0,,id=156262,00.html).

Henry Ordower, Professor of Law

Saint Louis University School of Law

U.S. National Report: The Burden of Proof in Tax Matters 
not there was a substantial misstatement on the basis of a reasonable method and contemporaneous documentation, ${ }^{252}$ is subject to a twenty percent penalty, ${ }^{253}$ forty percent in the case of a gross valuation misstatement. ${ }^{254}$ As a penalty, the IRS generally would have the burden to produce evidence in support of its position. ${ }^{255}$ This accuracy related penalty, however, is a strict liability penalty in the case of a transfer pricing adjustment. The substantial valuation misstatement attributable to a transfer price adjustment draws the penalty even in the absence of negligence or fraud. ${ }^{256}$ The IRS only need assess a deficiency with a transfer pricing adjustment in order to impose the penalty. Despite the automatic liability for the penalty if the transfer price adjustment meets the threshold, the transfer price directive anticipates that the audit team may elect not to impose the penalty. ${ }^{257}$

Unless (i) the taxpayer proves by a preponderance of the evidence that the tax deficiency attributable to a transfer pricing adjustment is incorrect or (ii) shifts the burden of proof to the government by producing credible evidence in support of its transfer price and the IRS is unable to prove the deficiency by a preponderance of the evidence, ${ }^{258}$ the penalty follows automatically. The IRS need provide no further proof to support the penalty. Thus, a taxpayer that fails to avoid the transfer price adjustment itself avoids the penalty only if the valuation misstatement remains below the substantial misstatement threshold. ${ }^{259}$ Establishing the reasonableness of the transfer price method and maintaining and producing contemporaneous documentation supporting the propriety of the method the taxpayer erroneously chose aids the taxpayer in avoiding the threshold, but not the penalty if the threshold is met. While the statutory language does not specify expressly that the taxpayer must establish that it has used a reasonable method, the taxpayer implicitly bears that burden since the IRS has no obligation to prove the taxpayer's case. ${ }^{260}$

The penalty statute does not specify the documentation that the taxpayer must produce but provides only a very broad outline of the documentation requirement. ${ }^{261}$ The Treasury regulations provide a more detailed description of the documentation requirement although they too are short on documentation specifics as opposed to principles. ${ }^{262}$ The regulations divide documentation into two categories: (i) principal documents consisting primarily of description of the taxpayer, transaction, transfer

\footnotetext{
252 The exclusion of amounts based upon the reasonableness of the taxpayer's method and its contemporaneous documentation goes only to whether or not there is a substantial valuation misstatement. The taxpayer may not exclude those amounts from the measure of the misstatement once the misstatement amount has met the threshold level. I.R.C. $\S 6662(\mathrm{e})(3)$.

${ }^{253}$ I.R.C. $\$ 6662(a)$.

${ }^{254}$ I.R.C. $\$ 6662(\mathrm{~h})$.

${ }^{255}$ I.R.C. $\$ 7491(\mathrm{c})$.

${ }^{256}$ I.R.C. $\$ 6662(\mathrm{a})$.

${ }^{257}$ Directive Transfer Pricing Compliance, supra note 251, at "Section 6662(e) penalty" item 3.

${ }^{258}$ I.R.C. $\$ 7491$ (a).

${ }^{259}$ I.R.C. $\$ 6662(\mathrm{e})(1)(\mathrm{B})$.

${ }^{260}$ I.R.C. $\$ 6662(\mathrm{e})(3)(\mathrm{B})(\mathrm{i})(\mathrm{I})$ uses the passive voice: "it is established" rather than stating that the taxpayer must establish.

${ }^{261}$ I.R.C. $\$ 6662(e)(3)(B)(i)(I I)$, for example, reads in part: "the taxpayer has documentation (which was in existence as of the time of filing the return) which sets forth the determination of such price in accordance with such a method and which establishes that the use of such method was reasonable ..."

${ }^{262}$ Treas. reg. $\$ 1.6662-6(d)($ iii).
}

Henry Ordower, Professor of Law

Saint Louis University School of Law

U.S. National Report: The Burden of Proof in Tax Matters 
pricing method and reasons for the choice of method and (ii) background documents consisting of data and other documents that support the choice of method. In the section on background documents there is a cross-reference to a similar record maintenance requirement in the regulations that provides somewhat more detailed descriptions of the type of records the taxpayer should maintain in order to avail itself of a safe harbor on record maintenance for related party transactions, including transfer pricing. ${ }^{263}$ The applicable text of the penalty regulation reads in part:

(iii) Documentation requirement -- (A) In general. The documentation requirement of this paragraph (d)(2)(iii) is met if the taxpayer maintains sufficient documentation to establish that the taxpayer reasonably concluded that, given the available data and the applicable pricing methods, the method (and its application of that method) provided the most reliable measure of an arm's length result under the principles of the best method rule in $\S 1.482-1$ (c), and provides that documentation to the Internal Revenue Service within 30 days of a request for it in connection with an examination of the taxable year to which the documentation relates. With the exception of the documentation described in paragraphs (d)(2)(iii)(B) (9) and (10) of this section, that documentation must be in existence when the return is filed. The district director may, in his discretion, excuse a minor or inadvertent failure to provide required documents, but only if the taxpayer has made a good faith effort to comply, and the taxpayer promptly remedies the failure when it becomes known. The required documentation is divided into two categories, principal documents and background documents as described in paragraphs (d)(2)(iii) (B) and (C) of this section.

(B) Principal documents. The principal documents should accurately and completely describe the basic transfer pricing analysis conducted by the taxpayer. The documentation must include the following --

(1) An overview of the taxpayer's business, including an analysis of the economic and legal factors that affect the pricing of its property or services;

(2) A description of the taxpayer's organizational structure (including an organization chart) covering all related parties engaged in transactions potentially relevant under section 482 [26 USCS § 482], including foreign affiliates whose transactions directly or indirectly affect the pricing of property or services in the United States;

(3) Any documentation explicitly required by the regulations under section 482 [26 USCS § 482];

${ }^{263}$ Treas. reg. $§ 1.6662-6(d)($ iii)(C) refers to Treas. reg. $§ 1.6038$ A-3(c) that includes specific document maintenance requirements.

Henry Ordower, Professor of Law

Saint Louis University School of Law

U.S. National Report: The Burden of Proof in Tax Matters 
(4) A description of the method selected and an explanation of why that method was selected, including an evaluation of whether the regulatory conditions and requirements for application of that method, if any, were met;

(5) A description of the alternative methods that were considered and an explanation of why they were not selected;

(6) A description of the controlled transactions (including the terms of sale) and any internal data used to analyze those transactions. For example, if a profit split method is applied, the documentation must include a schedule providing the total income, costs, and assets (with adjustments for different accounting practices and currencies) for each controlled taxpayer participating in the relevant business activity and detailing the allocations of such items to that activity. Similarly, if a cost-based method (such as the cost plus method, the services cost method for certain services, or a comparable profits method with a cost-based profit level indicator) is applied, the documentation must include a description of the manner in which relevant costs are determined and are allocated and apportioned to the relevant controlled transaction.

(7) A description of the comparables that were used, how comparability was evaluated, and what (if any) adjustments were made;

(8) An explanation of the economic analysis and projections relied upon in developing the method. For example, if a profit split method is applied, the taxpayer must provide an explanation of the analysis undertaken to determine how the profits would be split;

(9) A description or summary of any relevant data that the taxpayer obtains after the end of the tax year and before filing a tax return, which would help determine if a taxpayer selected and applied a specified method in a reasonable manner; and

(10) A general index of the principal and background documents and a description of the recordkeeping system used for cataloging and accessing those documents.

(C) Background documents. The assumptions, conclusions, and positions contained in principal documents ordinarily will be based on, and supported by, additional background documents. Documents that support the principal documentation may include the documents listed in $\S 1.6038 \mathrm{~A}-3$ (c) that are not otherwise described in paragraph (d)(2)(iii)(B) of this section. Every document listed in those regulations may not be relevant to pricing determinations under the taxpayer's specific facts and circumstances and, therefore, each of those 
documents need not be maintained in all circumstances. Moreover, other documents not listed in those regulations may be necessary to establish that the taxpayer's method was selected and applied in the way that provided the most reliable measure of an arm's length result under the principles of the best method rule in $\S 1.482-1$ (c).

Background documents need not be provided to the Internal Revenue Service in response to a request for principal documents. If the Internal Revenue Service subsequently requests background documents, a taxpayer must provide that documentation to the Internal Revenue Service within 30 days of the request. However, the district director may, in his discretion, extend the period for producing the background documentation. $^{264}$

B. Documentation and International Cooperation. The United States is a member of the Pacific Association of Tax Administrators ("PATA"). PATA which also includes Australia, Canada, and Japan has issued a cooperative statement on transfer pricing documentation that enables multinational entity taxpayers to maintain a uniform set of records for transfer pricing between or among related entities operating in differing PATA jurisdictions. ${ }^{265}$ PATA designed the documentation package to be consistent with OECD guidelines. The package includes a description of appropriate documentation in tabular form.

C. Advance Pricing Agreements. Perhaps the most important development in the United States with respect to creating greater certainty in transfer pricing has been the increasing availability of advance pricing agreements ("APA"). Under its advance ruling authority to issue binding guidance to taxpayers on specific transactions in advance of consummation of the transactions, the IRS, acting through the office of the Associate Chief Counsel (International), may rule in advance on a taxpayer's transfer pricing method. ${ }^{266}$ If the taxpayer and the IRS agree to an APA, the IRS may permit the taxpayer to apply the transfer pricing method to tax years prior to the effective date of the APA. ${ }^{267}$

The APA application process requires that the taxpayer submit documentation relating both to its business generally and the selected transfer pricing method with respect to which it requests an agreement with the IRS. The APA process may be unilateral involving only the United States taxpayer and the IRS or be bilateral or multilateral and include participation of the competent authority representative of the United States and from the jurisdictions or jurisdictions in which the taxpayer's related party is located. Documentation requirements are similar to, but more specific and extensive than, those under the transfer pricing penalty regulations. ${ }^{268}$ As long as the taxpayer complies with the APA, the transfer prices that the taxpayer establishes under the transfer pricing method of the APA are arm's length prices and

\footnotetext{
${ }^{264}$ Treas. reg. §1.6662-6(d)(iii).

${ }^{265}$ Pacific Association of Tax Administrators (PATA) Transfer Pricing Documentation Package (available at http://www.irs.gov/businesses/international/article/0,id=156266,00.html).

${ }^{266}$ Rev. Proc. 91-22; 1991-1 C.B. 526, superseded by Rev. Proc. 96-53, 1996-2 C.B. 375, further superseded by Rev. Proc. 2004-40, 2004-2 C.B. 50, and superseded most recently by Rev. Proc. 2006-9, 2006-1 C.B. 278, as modified by Rev. Proc. 2008-31, 2008-1 C.B. 1133. See, also, Rev. Proc. 2006-54; 2006-2 C.B. 1035 (procedures for requesting competent authority assistance to prevent double taxation under a treaty in the event of I.R.C. $\$ 482$ reallocations.

${ }^{267}$ Rev. Proc. 2006-9; 2006-1 C.B. 278, supra note 266, at Section 2.12 ("rollback" of APA) and Section 8.

${ }^{268}$ Treas. reg. $\S 1.6662-6(\mathrm{~d})(\mathrm{iii})$, supra note 264 and accompanying text.
}

Henry Ordower, Professor of Law

Saint Louis University School of Law

U.S. National Report: The Burden of Proof in Tax Matters 
constitute the best transfer pricing method for the United States taxpayer and the transactions subject to the APA. ${ }^{269}$ APAs permit some flexibility to make compensating adjustments when operating results deviate from those that the APA's method anticipated. The taxpayer may take the compensating adjustments into account in the transfer price. ${ }^{270}$

The IRS reports annually in a public document on the operation of the APA program. $^{271}$ The most recent report ${ }^{272}$ includes the form of the Model APA Agreement that is the basis for the specific agreements with taxpayers. ${ }^{273}$ The IRS has received a total of 1379 applications since inception of the APA program and received 127 of that total in 2009. The IRS has executed 904 APAs of which 361 were unilateral, 464 bilateral, 13 multilateral. It entered into 63 APAs in 2009. The largest number of APAs in 2009 involved the sale of tangible property or the provision of services and the IRS agreed to a wide range of transfer pricing methodologies. Further expansion of the program ideally will eliminate a significant area of dispute between taxpayers and the IRS, and, if used effectively with the involvement of competent authorities, has the potential to bolster international cooperation on tax matters.

23. Imposition of penalties and burden of proof. See Section A of response to question 22.

24. Type of documents to be provided. See Section A of response to question 22 for general documentation requirements. The Treasury regulations governing transfer pricing require the taxpayer to do functional analysis in order to ascertain the degree of comparability between controlled and uncontrolled transactions. ${ }^{274}$ Unless legal barriers to disclosure of information in a foreign jurisdiction interfere, the United States taxpayer generally must produce documentation in the possession of a controlled or controlling company or one under common control with the taxpayer in order to meet its burden of proof on the validity of its transfer pricing.

25. Choice of transfer pricing method. The taxpayer must choose the best method for providing an arm's length transfer price. ${ }^{275}$ Depending on the facts and circumstances of the transaction, the taxpayer will have a variety of methods to evaluate in choosing the correct method and must perform comparability analyses ${ }^{276}$ and consider the arm's length range ${ }^{277}$ in the evaluation. The range of methods under consideration differs depending upon the transaction.

For transfers of tangible property, six methods are possible any one of which may prove to be the best method. ${ }^{278}$ Possible methods include (i) comparable uncontrolled price, ${ }^{279}$ (ii) resale price, ${ }^{280}$ (iii) cost plus, ${ }^{281}$ (iv) comparable profits, ${ }^{282}$ (v) profit split, ${ }^{283}$ and

${ }^{269}$ Rev. Proc. 2006-9; supra note 266, at Section 10.02.

${ }^{270} I d$. at Section 11.02

${ }^{271}$ Section 521(b) of the Tax Relief Extension Act of 1999, PL 106-170 (December 17, 1999) (requires the reporting)

${ }^{272}$ Announcement 2010-21; 2010-15 I.R.B. 551.

${ }^{273}$ Id., Attachment A.

${ }^{274}$ Treas. reg. $\$ 1.482-1(d)(3)(i)$ (requiring functional analysis and identifying functions for comparison).

${ }^{275}$ Treas. reg. $\$ 1.482-1(\mathrm{c})$.

${ }^{276}$ Treas. reg. $\$ 1.482-1(\mathrm{~d})$.

277 Treas. reg. $\$ 1.482-1(\mathrm{e})$.

${ }^{278}$ Treas. reg. $\$ 1.482-3(\mathrm{a})$.

${ }^{279}$ Treas. reg. $\$ 1.482-3(\mathrm{~b})$

Henry Ordower, Professor of Law

Saint Louis University School of Law

U.S. National Report: The Burden of Proof in Tax Matters 
(vi) unspecified methods. ${ }^{284}$ For intangible property, however, only (i) comparable uncontrolled price, (ii) comparable profits, (iii) profit split, and (iv) unspecified methods are available. Resale price and cost plus do not apply. ${ }^{285}$ Neither the statute nor the regulations identify a hierarchy in the methods, but rather provide examples of different transactions for which differing methods would be best. ${ }^{286}$ Absence of a hierarchy is consistent with the current OECD guidelines. ${ }^{287}$

26. Burden of proof and bilateral conventions. In the United States, the taxpayer bears the burden of proof but may shift that burden to the government by producing credible evidence in support of its position. ${ }^{288}$ Moreover, Appeals has broad authority to compromise a taxpayer's liability based upon an evaluation of the hazards of litigation. ${ }^{289}$ In settlement negotiation with the IRS and in litigation, only United States law determines the United States tax consequences of the setting of correct transfer prices, so that there is certainly a risk of inconsistent outcomes in proceedings in different jurisdictions. Double taxation or no taxation are both possible outcomes.

In order to eliminate cross border uncertainty in transfer pricing, the IRS offers taxpayers the opportunity to enter into bilateral and multilateral APAs. ${ }^{290}$ In bilateral and multilateral APAs, the taxpayer applies to the IRS and requests the participation of competent authority. ${ }^{291}$ The United States competent authority negotiates with the competent authority of other jurisdictions in which the taxpayer's related parties are located under the mutual agreement procedure of the applicable tax treaties or other international agreements. ${ }^{292}$ Broad acceptance of the APA model would eliminate the risk of double taxation or no taxation through a negotiated settlement on a transfer pricing method.

27. Burden of proof and information exchange procedures. While the IRS may make use of exchange of information treaty provisions or tax information exchange agreements, it need not. The IRS may determine a taxpayer's tax liability based upon information the taxpayer reports, and the taxpayer has the burden to prove the IRS's determination is not correct. Unless the taxpayer produces records and documentation as the Code requires, including regulations that correctly interpret the Code, ${ }^{293}$ the taxpayer may not shift the burden of proof to the IRS. Thus the taxpayer has the burden to produce data from outside the United States that is not otherwise available to the IRS, except through a treaty's

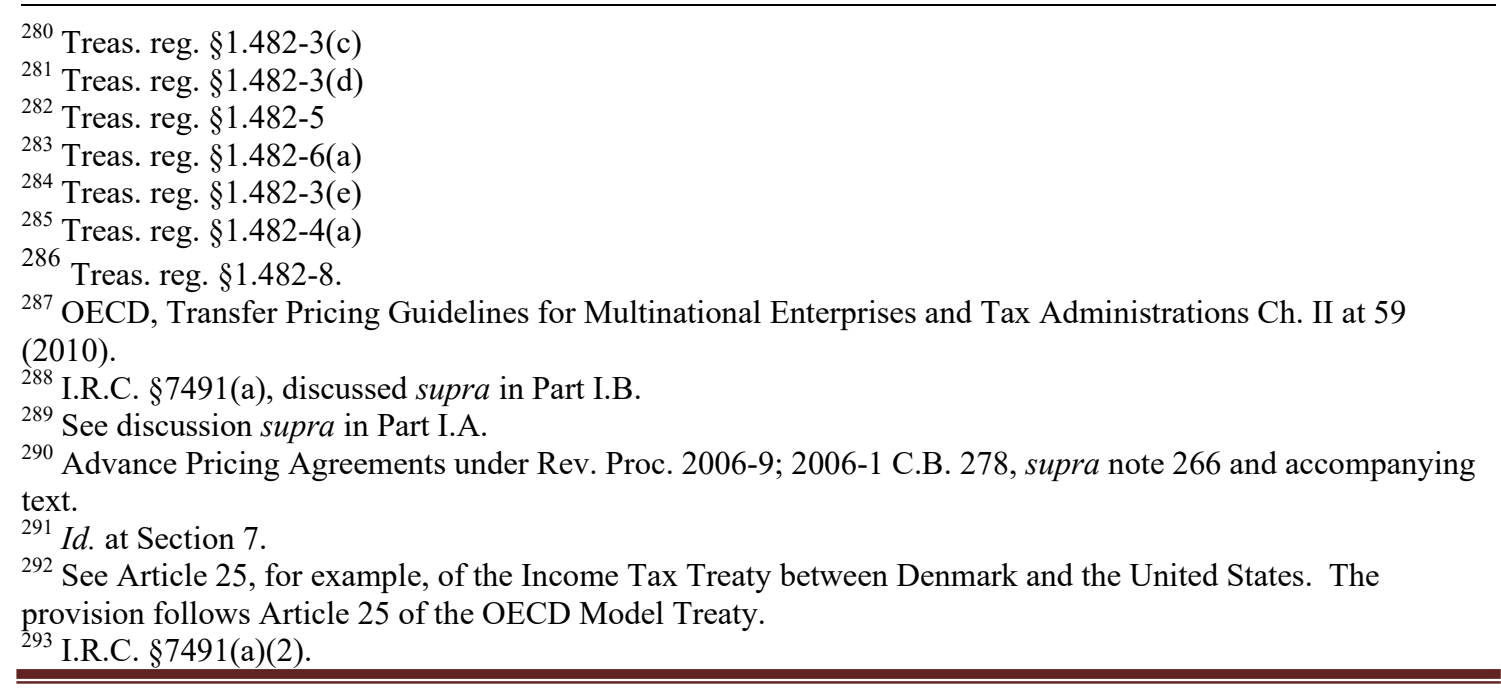

Henry Ordower, Professor of Law

Saint Louis University School of Law

U.S. National Report: The Burden of Proof in Tax Matters $\quad$ Page 34 
exchange of information provision, if that data is critical to determination of the best transfer pricing method.

28. Burden of proof in the mutual agreement procedure. See response to question 26 identifying the APA process. 